\title{
Interconvertible geometric isomers of Plasmodium falciparum dihydroorotate dehydrogenase inhibitors exhibit multiple binding modes
}

Glenn A. McConkey ${ }^{\mathrm{a}}$, Paul T. P. Bedingfield ${ }^{\mathrm{a}}$, David R. Burrell ${ }^{\mathrm{b}}$, Nicholas C. Chambers ${ }^{\mathrm{b}}$, Fraser Cunningham ${ }^{\mathrm{c}}$, Timothy J. Prior ${ }^{\mathrm{b}}$, Colin W.G. Fishwick ${ }^{\mathrm{c}}$, Andrew N. Boa ${ }^{\mathrm{b}^{*}}$

${ }^{a}$ School of Biology, Faculty of Biological Sciences, University of Leeds, Leeds LS2 9JT, UK

${ }^{b}$ School of Mathematics \& Physical Sciences, Faculty of Science and Engineering, University of Hull, Hull HU6 7RX, UK

${ }^{c}$ School of Chemistry, Faculty of Mathematics and Physical Sciences, University of Leeds, Leeds LS2 9JT, UK

\begin{abstract}
Two new tricyclic $\beta$-aminoacrylate derivatives (2e and $\mathbf{3 e}$ ) have been found to be inhibitors of Plasmodium falciparum dihydroorotate dehydrogenase (PfDHODH) with $\mathrm{Ki} 0.037$ and $0.15 \mu \mathrm{M}$ respectively. ${ }^{1} \mathrm{H}$ and ${ }^{13} \mathrm{C}$ NMR spectroscopic data show that these compounds undergo ready cis-trans isomerisation at room temperature in polar solvents. In silico docking studies indicate that for both molecules there is neither conformation nor double bond configuration which bind preferentially to PfDHODH. This flexibility is favourable for inhibitors of this channel that require extensive positioning to reach their binding site.
\end{abstract}

Keywords: dihydroorotate dehydrogenase; DHODH; Plasmodium falciparum; inhibitor *Corresponding author. Tel.: +44 (0)1482 465022; E-mail address: a.n.boa@hull.ac.uk 
Malaria is one of the main infectious diseases in the world with an estimated 212 million cases in 2015, centred to a great extent on the countries in central Africa and south east Asia. ${ }^{1}$ The numbers are even starker when one considers it is estimated these cases led to an estimated 429,000 deaths and that approximately $70 \%$ of these deaths were of children under five years old. Malaria is considered a 'preventable' disease, largely because of the use of chemotherapeutic agents, ${ }^{2}$ however widespread drug resistance ${ }^{3}$ has rendered these agents ineffective in many regions of the world. This problem has led to much effort being expended into validating novel drug targets, as well as discovering small molecule enzyme inhibitors to act as leads for development of new antimalarial drugs. ${ }^{4}$ One such target which has attracted recent attention is $P$. falciparum dihydroorotate dehydrogenase (PfDHODH) ${ }^{5}$ a key enzyme in the obligate de novo pyrimidine pathway for uridine monophosphate (UMP) biosynthesis. Early work aimed towards the discovery of PfDHODH inhibitors focussed on modification of the human DHODH $(h \mathrm{DHODH})$ inhibitors known at the time, such as brequinar (Figure 1). ${ }^{6}$ This work was naturally followed by high throughput screening ${ }^{7}$ and de novo design approaches. ${ }^{8}$ During the progress of this work, co-crystallisation ${ }^{9}$ and in silico docking ${ }^{8,10}$ experiments revealed that the inhibitors discovered targeted the ubiquinone binding channel, and also revealed important features for the design of selective and potent inhibitors. Firstly amino acid residues H185 and / or R265, at the head of the ubiquinone-binding channel, were found to be essential for hydrogen bonding interactions with the inhibitors. The ubiquinone channel also contained a hydrophobic region which contributes to the binding of the more potent inhibitors reported. Indeed many of the inhibitors reported to date ${ }^{6-12}$ reveal broadly this amphiphilic nature, and possess a polar 'head group' and hydrophobic 'tail'. Triazolopyrimidine DSM265 (Figure 1) is currently the most advanced PfalDHODH inhibitor, and Phase 1 clinical trials for this candidate have recently been reported. ${ }^{13}$

We have reported previously that $\beta$-aminoacrylate derivatives of the general structure 1 (Figure 1) are inhibitors of PfDHODH. ${ }^{10}$ In particular, tricyclic derivatives $\mathbf{2 a}$ and $\mathbf{3 b}$ displayed sub-micromolar 
IC50 values against $P f D H O D H$, and in the case of 2a there was a 1000-fold greater potency compared to the human enzyme ( $h \mathrm{DHODH})$. An extensive series of experiments in this previous work with this class of inhibitors ${ }^{10 a}$ showed that compounds $\mathbf{2 a}$ and $\mathbf{3 b}$, and related structures, were competitive inhibitors with the enzyme cofactor CoQ and reversible. Compounds such as $\mathbf{2 a}$ may in principle exist as a pair of geometric isomers and we considered that different $\mathrm{H}$-bonding groups on either side of the double bond, and their position relative to the aromatic portion of the structure through rotation about the $\mathrm{C}_{\mathrm{Ar}} \mathrm{r}$ - bond, would be key in determining their binding to the enzyme. It is perhaps noteworthy to mention that alternative binding modes have been reported with certain $h$ DHODH inhibitors, ${ }^{14}$ and also differential binding modes for A77 1726, the active metabolite of leflunomide (Figure 1), when binding to PfDHODH is compared to its principal target $h \mathrm{DHODH} .{ }^{9 \mathrm{a}}$ We therefore sought to examine whether alterative polar 'head groups' to those investigated would lead to improved activity of members in this class of compound, and the results obtained are reported herein. 
<smiles>Cc1c(-c2ccc(-c3ccccc3F)cc2)nc2ccc(F)cc2c1C(=O)O</smiles>

brequinar<smiles>Cc1cc(Nc2ccc(S(F)(F)F)cc2)n2nc(C(C)(F)F)nc2n1</smiles>

DSM265

$\mathrm{R}=\mathrm{CO}_{2} \mathrm{Et}$

$\mathrm{R}=\mathrm{CN}$

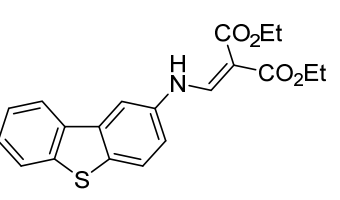

$3 b$<smiles>CC(O)=C(C#N)C(=O)Nc1ccc(C(F)(F)F)cc1</smiles>

A77 1726

Figure 1. Example structures of known PfalDHODH (brequinar, DSM265, 2a and 3b) and $h$ DHODH (A77 1726) inhibitors.

Ten new derivatives (2b-f, 3a,c-f) based on the 3-aminocarbazole (4) and 3aminodibenzothiophene (5) core unit were synthesised using the method reported previously (Scheme 1). ${ }^{10 a}$ Derivatives $\mathbf{2} \mathbf{b}$ and $\mathbf{3 a}$ were prepared by simply heating the aromatic amine with the appropriate commercially available $\beta$-ethoxy- $\alpha, \beta$-unsaturated carbonyl compound $\mathbf{6 b}$ and $\mathbf{6 a}$ respectively. For $\mathbf{2 c}-$ f and 3c-f the relevant active methylene compounds $7 \mathbf{c - f}$ were first heated with an excess of triethylorthoformate (or acetate) in toluene, forming the $\beta$-ethoxy- $\alpha, \beta$-unsaturated carbonyl compounds $\mathbf{6 c - f}$ in situ, followed by addition of either the aromatic amine $\mathbf{4}$ or $\mathbf{5}$ and heating for a further short period. After cooling, the products precipitated upon standing, were collected by filtration and then recrystallised. ${ }^{15}$ 


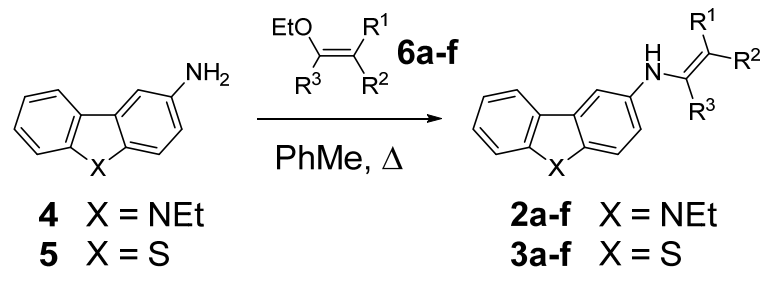

$$
\begin{aligned}
& \text { a } \mathrm{R}^{1}=\mathrm{CO}_{2} E t, \mathrm{R}^{2}=\mathrm{CN},\left(\mathrm{R}^{3}=\mathrm{H}\right) \\
& \text { b } \mathrm{R}^{1}=\mathrm{CO}_{2} \mathrm{Et}, \mathrm{R}^{2}=\mathrm{CO}_{2} \mathrm{Et},\left(\mathrm{R}^{3}=\mathrm{H}\right) \\
& \text { c } \mathrm{R}^{1}=\mathrm{R}^{2}=\mathrm{COCH}_{3},\left(\mathrm{R}^{3}=\mathrm{H}\right) \\
& \text { d } \mathrm{R}^{1}, \mathrm{R}^{2}=-\mathrm{CO}_{2} \mathrm{C}(\mathrm{Me})_{2} \mathrm{O}_{2} \mathrm{C}-,\left(\mathrm{R}^{3}=\mathrm{H}\right) \\
& \text { e } \mathrm{R}^{1 / 2}=\mathrm{NO}_{2}, \mathrm{R}^{2 / 1}=\mathrm{CO}_{2} \mathrm{Et},\left(\mathrm{R}^{3}=\mathrm{H}\right) \\
& \text { f } \mathrm{R}^{1}=\mathrm{CO}_{2} \mathrm{Et}, \mathrm{R}^{2}=\mathrm{CN},\left(\mathrm{R}^{3}=\mathrm{CH}_{3}\right)
\end{aligned}
$$

Scheme 1. Synthesis of $\beta$-aminoacrylate derivatives of 9-ethyl-3-aminocarbazole and 3aminodibenzothiophene in this study.

Table 1 shows the $\mathrm{IC}_{50}$ values obtained for the compounds discussed in this work. These values were

\begin{tabular}{|c|c|c|}
\hline Entry & $\begin{array}{c}\text { PfalDHODH } \\
\text { IC }_{50}(\mu \mathrm{M})\end{array}$ & $\begin{array}{l}\text { hDHODH } \\
\mathrm{IC}_{50}(\mu \mathrm{M})\end{array}$ \\
\hline $2 \mathbf{a}$ & $\begin{array}{c}0.28 \pm 0.05 \\
0.44 \pm 0.06^{10 a}\end{array}$ & $491 \pm 42^{10 a}$ \\
\hline 3a & 1.2 & n.d. \\
\hline $2 \mathbf{b}$ & 4.4 & n.d. \\
\hline $3 \mathbf{b}$ & $\begin{array}{c}0.16 \pm 0.05 \\
0.16 \pm 0.05^{10 a}\end{array}$ & $30 \pm 5.9^{10 a}$ \\
\hline $2 \mathrm{c}$ & $>100$ & n.d. \\
\hline $3 c$ & $>100$ & n.d. \\
\hline $2 d$ & $>100$ & n.d. \\
\hline 3d & $>100$ & n.d. \\
\hline $2 e$ & $0.094 \pm 0.031^{\dagger}$ & $>100$ \\
\hline $3 e$ & $0.38 \pm 0.06 \$$ & $>100$ \\
\hline $2 f$ & $>100$ & n.d. \\
\hline $3 f$ & $>100$ & n.d. \\
\hline
\end{tabular}
obtained using the screening methodology reported previously. ${ }^{10 a}$ The $\mathrm{IC}_{50}$ values of derivatives $\mathbf{2 c , d , f}$ and $\mathbf{3 c}, \mathbf{d}, \mathbf{f}$ were above the arbitrary cut-off value of $0.1 \mathrm{mM}$ and thus not further examined. Derivatives 2d and 3d, structures based upon Meldrum's acid, are conformationally restricted analogues. We assigned their low activity to the restricted freedom imposed by the six-membered ring to position the polar head group for maximal hydrogen bonding to H-bond donors on either side the co-factor channel. 
Table 1. IC 50 values of selected compounds against $P$. falciparum and human DHODH. The $\mathrm{IC}_{50}$ values were determined according to methodology reported previously. ${ }^{10 \mathrm{a}}$ n.d. $=$ not determined; $\uparrow \mathrm{Ki}$ vs PfalDHODH) for $\mathbf{2 e}$ was $0.037 \pm 0.012 \mu \mathrm{M}$; $+\mathrm{Ki}(\mathrm{PfalDHODH}$ ) for $\mathbf{3 e}$ was $0.150 \pm 0.001 \mu \mathrm{M}$ (cf. Ki $=0.05$ and $0.02 \mu \mathrm{M}$ for $\mathbf{2 a}$ and $3 \mathbf{b}$ respectively ${ }^{10 \mathrm{a}}$ )

The activity of the cyanoacetate $(\mathbf{2} \mathbf{a}, \mathbf{3 a})$ and malonate derivatives $(\mathbf{2} \mathbf{b}, \mathbf{3} \mathbf{b})$ are not too dissimilar, and the $\mathrm{IC}_{50}$ values are probably subtly altered depending on the influence of the second ethyl ester and/or $N$-ethyl group. The lowest activity is seen with $\mathbf{2 b}$, where both ethyl groups are present, may mean that the molecule is slightly too large to fit well into the ubiquinone binding site. Similarly, derivatives $\mathbf{2 f}$ and $\mathbf{3 f}$, which only differ from $\mathbf{2 a}$ and $\mathbf{3 a}$ by a single methyl group, showed that substitution at this position cannot be tolerated sterically. The lack of activity in $\mathbf{2 c}$ and $\mathbf{3 c}$ was somewhat surprising, given the similar electron withdrawing effect of the methyl ketone compared to the ethyl ester and cannot so easily be explained.

Nitroacrylate derivatives $\mathbf{2 e}$ and $\mathbf{3 e}$ were as active, if not more so, than cyanoacrylate and malonate derivatives $\mathbf{2 a , b}$ and $\mathbf{3 a}, \mathbf{b}$. As discussed above, we considered that the conformational preferences in the polar 'head group' would be important in determining the binding mode of these inhibitors to DHODH, and so it was interesting in particular to compare the isomerism in carbazole derivatives $2 \mathbf{a}, \mathbf{2 e}$ and $\mathbf{2 f}$, and the corresponding analogues of the dibenzothiophene series $\mathbf{3 a}, \mathbf{3 e}$ and 3f. In the case of $\mathbf{2 a}$ and $\mathbf{3 a}$, evidence of only one isomer is seen in the ${ }^{1} \mathrm{H}$ NMR. The heavily deshielded $\mathrm{NH}(\delta 10.96 \mathrm{ppm}$ for $\mathbf{2 a}$ and $11.26 \mathrm{ppm}$ for $\mathbf{3 a})$ and large coupling to the $-\mathrm{CH}=(J 13.7 \mathrm{~Hz})$ indicated the presence of intramolecular hydrogen bonding to the ester carbonyl group, and the antidisplacement of the hydrogen atoms in the $\mathrm{Ar}-\mathrm{NH}-\mathrm{CH}=$ unit showed that the $(\mathrm{Z})$-isomer was preferred. In the case of $\mathbf{2 f}$ and $\mathbf{3 f}$ analysis of the products similarly revealed single isomers [ $\delta_{\mathrm{NH}} 11.56(\mathrm{~s})$ for $\mathbf{2 f}$, and $\delta_{\mathrm{NH}} 11.65$ (s) for $\left.\mathbf{3 f}\right]$ in spite of the extra methyl group $\left(\mathrm{R}^{3}\right)$. The nitroacrylate derivatives $2 \mathrm{e}$ and 3e have the possibility to exhibit intramolecular hydrogen bonding in either isomeric form, and the balance between these isomeric forms was expected to have an important effect on the overall isomeric 
preferences and therefore binding to the cofactor channel of DHODH. The ${ }^{1} \mathrm{H}$ NMR of both $\mathbf{2 e}$ and $\mathbf{3 e}$ showed a 1:1 mixture (in $\mathrm{CDCl}_{3}$ ) however many times it was recrystallised under a range conditions (solvent, rate of cooling etc), indicating no clear preference in solution for one isomer over the other. ${ }^{16}$ The ${ }^{13} \mathrm{C}$ NMR of $\mathbf{2 e}$ in $\mathrm{CDCl}_{3}$ showed doubling of almost all signals. However for $\mathbf{3 e}$ in the more polar $d_{6}$-DMSO only one set of the aromatic carbon signals and ethyl group were observed, and also the signals for the acrylate unit were completely absent. This was accompanied by changes in the ${ }^{1} \mathrm{H}$ NMR where in $d_{6}$-DMSO the $\mathrm{NH}-\mathrm{CH}=$ signals were broadened significantly and almost reduced to baseline level, and the ethyl $\mathrm{CH}_{2}$ quartet was greatly broadened. This indicates clearly that the geometric forms of $3 \mathbf{e}$ are readily interconvertible in a polar solvent on the NMR timescale.

Carbazole 2e could be recrystallised from ethyl acetate to provide bright red crystals suitable for single crystal X-ray diffraction (see Supplementary Information). ${ }^{17}$ The first crop showed $2 \mathrm{e}$ had crystallised preferentially as the (Z)-isomer (Figure 2A). Examining the single crystal X-ray data of 2e it was interesting to find that the N2-C15 bond was much shorter than the $\mathrm{C} 15-\mathrm{C} 16$ bond and $\mathrm{C} 9-\mathrm{N} 2$

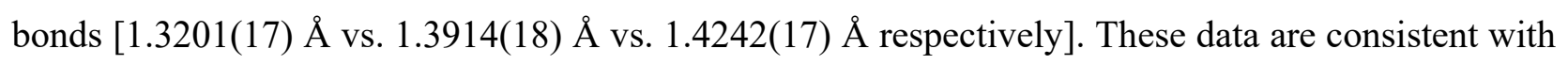
extensive delocalisation of the nitrogen lone pair into the enamine unit in the (Z)-isomer (Figure 2B), and could explain its deep red colour. After evaporation of the mother liquors and another recrystallization, the quality of the red crystals diminished and an orange powder was obtained upon evaporation of the mother liquors. Optical microscopy of this material showed two microcrystalline forms, one red and one orange, with the latter in large excess. We surmised the orange material may be the more soluble $(E)$-isomer. A portion of the orange powder was examined by X-ray powder diffraction using a PANAlytical Empyrean diffractometer operating with $\mathrm{Cu} \mathrm{K} \alpha_{1}$ radiation. It was shown to be highly crystalline, but the diffraction pattern of the orange powder did not match that calculated from the structure of the red crystals obtained (Supplementary Information Figure S1). It was possible to index the powder diffraction pattern of the orange powder using a large triclinic cell. 
The volume of this cell $\left(2506 \AA^{3}\right)$ is approximately three times that of the cell found for the red crystals. It seems likely that the bulk of the orange sample contains the $(E)$ isomer of $\mathbf{2 e}$, and the tripling of the volume suggests that there are three molecules in the asymmetric unit, perhaps two of one isomeric form and one of the other. Importantly, ${ }^{1} \mathrm{H}$ NMR of either the red or orange crystalline forms showed, in $\mathrm{CDCl}_{3}$ solution, the same 1:1 mixture of the two geometric isomers.

We were able to select a small single crystal of the orange material from among the original red crystals. The small crystal only diffracted weakly but we were able to obtain a crystal structure, albeit of lower quality than that of the red form. ${ }^{18}$ The structure is not too dissimilar to that of the red crystals, however it had a different orientation of both the $N$-ethyl and ethyl ester groups (Supplementary Information Figure S2). It also showed that the nitro group was not co-planar with the $\mathrm{NH}$, as in the red crystals, but was inclined at an angle of $25(1)^{\circ}$. The crystal structure of this orange single crystal did not, however, match the powder diffraction pattern of the bulk orange material (Supplementary Information Figure S3). 


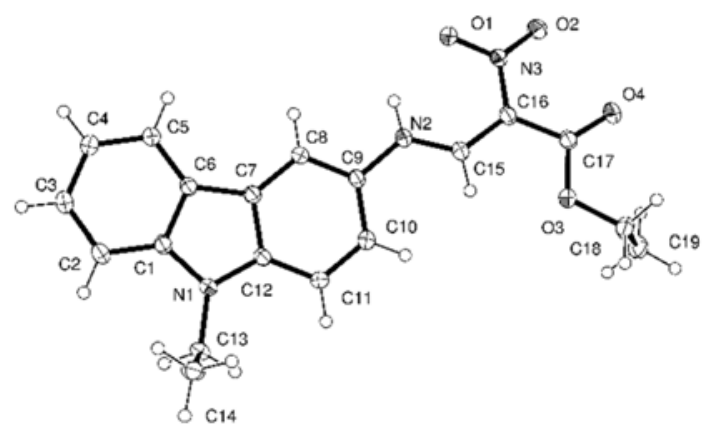

A

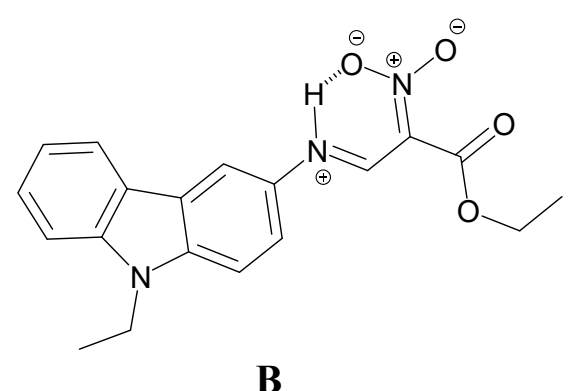

Figure 2A: Crystal structure of $2 \mathrm{e}$ with atoms drawn as 50\% thermal ellipsoids The more crystalline form of 2e reveals a shortened N2-C15 bond, lengthened $\mathrm{C} 15-\mathrm{C} 16$ bond and an intermolecular hydrogen bond between the nitro group and the NH. Figure 2B: The bond lengths from the crystal structure of the deep red coloured $2 \mathbf{e}$ is consistent with large degree of delocalisation of the nitrogen lone pair.

In order to probe the details of the interaction of these inhibitors with PfDHODH, docking (with both eHiTS and Autodock) of the $E$ - and Z-forms of $\mathbf{2 e}$ and $\mathbf{3 e}$ into the putative ubiquinione binding channel of PfDHODH was performed using the PfDHODH crystal structure (PDB code; 1TV5). The data produced suggest several possibilities for the binding of each isomer of $\mathbf{2 e}$ and $\mathbf{3 e}$ into PfDHODH. However all of the suggested poses are predicted to bind in the same general space of the enzyme, with the aromatic 'tail' group of each ligand binding deep within the large hydrophobic pocket of the binding site (Figures 3A and 3B). For each of the four structures (i.e. both $E$ - and Zisomers of both $\mathbf{2 e}$ and $\mathbf{3 e}$ ) two equally favourable rotamers were observed with the tail group seen to adopt the orientations shown in Figures 3A and 3B. 


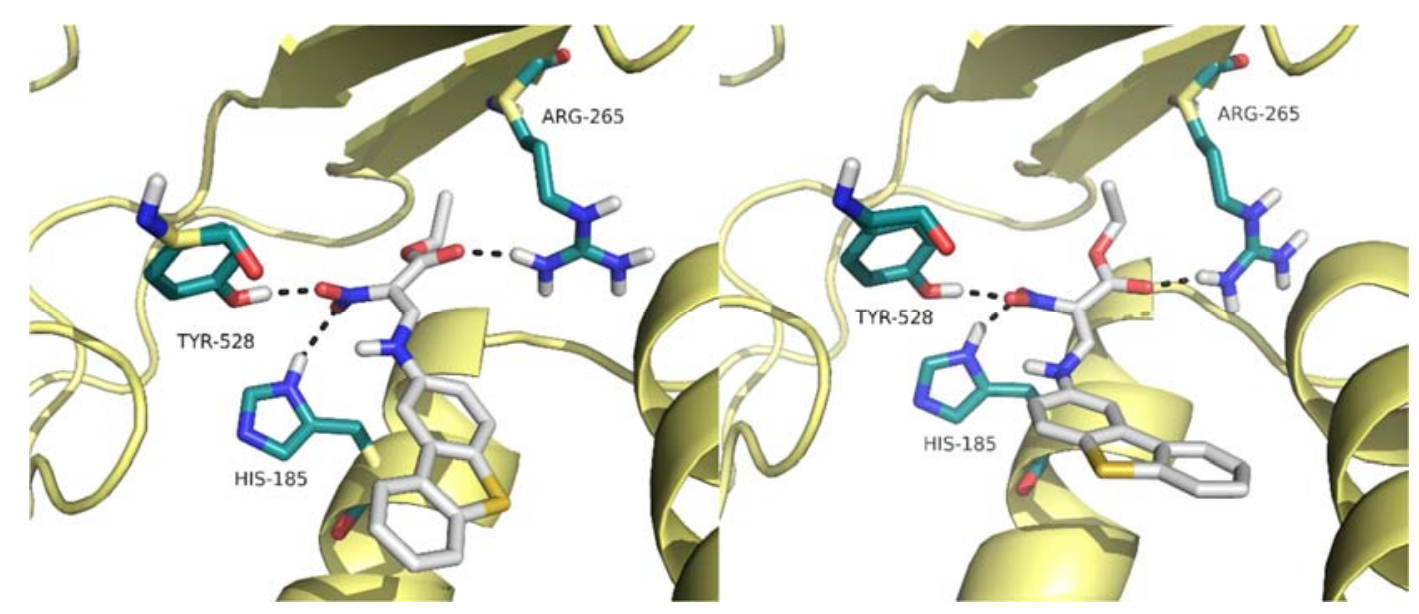

A

B

Figure 3. Docking studies reveal that the hydrophobic aromatic tail group of $\mathbf{3 e}$ (forest green) and 2e (latter not shown) may adopt one of two equally preferred conformations $\left(\mathbf{3 A}\right.$ and $\mathbf{3 B}$, rotated $180^{\circ}$ around the Ar-NH bond) when docked into the ubiquinone co-factor channel of PfDHODH. In both cases hydrogen bonding networks with Tyr528, His185 and Arg265 are maintained.

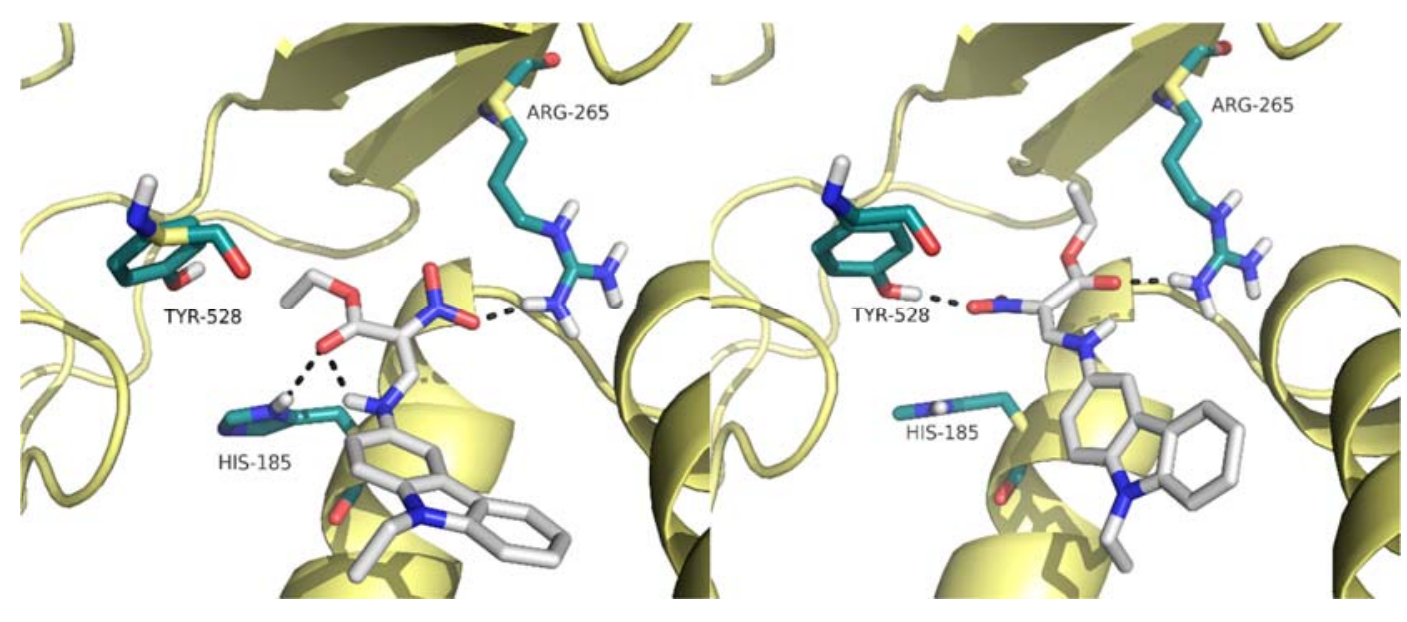

A

B

Figure 4. Docking studies reveal that the hydrophilic head group of $\mathbf{2 e}$ and $\mathbf{3 e}$ (latter not shown) may bind in two equally preferred conformations (4A and $\mathbf{4 B}$, rotated $180^{\circ}$ around the Ar- $\mathrm{NH}$ bond) when docked into the ubiquinone co-factor channel of PfDHODH.

For both molecules $\mathbf{2 e}$ and $\mathbf{3 e}$ the polar 'head group' of the molecule is predicted to bind in the polar region of the binding site. Both isomers of each molecule can adopt two distinct hydrogen 
bonding networks (Figures 4A and 4B). This is again due to a rotation of $180^{\circ}$ around $\mathrm{Ar}-\mathrm{NH}$ bond causing the polar 'head' of the molecule to flip. Although this 'flipping' forces a change in the hydrogen bonds made by the molecule and the enzyme, the residues involved in binding in PfDHODH are preserved, i.e. histidine 185 (H185), tyrosine 528 (Y528) and arginine 265 (R265). All suggested binding poses have hydrogen bonds to at least two of these residues. The results from the docking studies suggest that the ligands may bind with multiple poses to the ubquinone channel and that there is no clear preference for any one arrangement.

In conclusion, we have discovered two new derivatives (2e and $\mathbf{3 e}$ ) that are potent inhibitors of PfDHODH. ${ }^{1} \mathrm{H}$ and ${ }^{13} \mathrm{C}$ NMR spectroscopic data revealed that these compounds undergo ready isomerisation at room temperature in $d_{6}-\mathrm{DMSO}$, but the docking studies indicate that there is neither conformation nor configuration which binds preferentially to PfDHODH. This flexibility is favourable for inhibitors of this channel that require extensive positioning to reach their binding site. X-ray crystallographic study of the red crystal form of (Z)-2e reveals shortened N2-C15 and lengthened C15C16 bonds. The delocalisation of the charge onto the nitro group must promote the hydrogen bonding interactions between the nitro group and the N9-H, but also with any H-bond donor group on the enzyme. This is consistent with the observations made by Phillips and co-workers where an intrinsic dipole contribution ${ }^{9 b}$ in their triazolopyrimidine class of compounds is also believed to add to the hydrogen bonding and thus binding of the inhibitors to the enzyme. Overall, these results further add to the knowledge of inhibitor binding to the co-factor binding site of PfDHODH and may assist in the design and optimisation of other, more drug-like inhibitors of $P$. falciparum dihydroorotate dehydrogenase.

\section{Acknowledgements}


We thank the University of Hull for funding, BBSRC for support (GM), and the EPSRC National Mass Spectrometry Service (Swansea) for accurate mass determination of $\mathbf{2 e}$ and $\mathbf{3 e}$.

\section{References and notes}

1. World Malaria Report 2016, World Health Organisation, Geneva (http://www.who.int/malaria/publications/world-malaria-report-2016/en/).

2. Schlitzer, M. ChemMedChem 2007, 2, 944-986.

3. (a) Parija, S. C.; Praharaj, I. Indian J. Med. Microbiol. 2011, 29, 243-248; (b) White, N. J. J. Clin. Invest. 2004, 113, 1084-1092.

4. (a) MMV Global portfolio of antimalarial medicines 2016, https://www.mmv.org/sites /default/files/uploads/docs/RandD/4Q_2016_Global_Portfolio.pptx (accessed 19/4/2017); (b) Arora, N.; Banerjee, A.K. Mini-Rev. Med. Chem. 2012, 12, 210-226; (c) Burrows, J. N.; Waterson, D. Top. Med. Chem. 2011, 7, 125-180; (d) Burrows, J. N.; Chibale, K.; Wells, T. N. C. Curr. Top. Med. Chem. 2011, 11, 1226-1254; (e) Schlitzer, M.; Ortmann, R. ChemMedChem 2010, $5,1837-1840$.

5. (a) McRobert, L.; McConkey, G. A. Mol. Biochem. Parasitol. 2002, 119, 273-8; (b) Phillips, M. A.; Rathod, P. K. Infect. Dis. Drug Targ. 2010, 10, 226-239.

6. (a) Boa, A. N.; Canavan, S. P.; Hirst, P. R.; Ramsey, C.; Stead, A. M. W.; McConkey, G. A. Bioorg. Med. Chem. 2005, 13, 1945-1967; (b) Hurt, D. E.; Sutton, A. E.; Clardy, J. Bioorg. Med. Chem. Lett. 2006, 16, 1610-1615.

7. (a) Baldwin, J., Michnoff, C. H.; Malmquist, N. A.; White, J.; Roth. M. G.; Rathod, P. K.; Phillips, M. A. J. Biol. Chem. 2005, 280, 21847-21853; (b) Patel, V.; Booker, M.; Kramer, M.; Ross, L.; Celatka, C. A.; Kennedy, L. M.; Dvorin, J. D.; Duraisingh, M. T.; Sliz, P.; Wirth, D. F.; Clardy, J. J. Biol. Chem. 2008, 283, 35078-35085 (c) Booker, M. L.; Bastos, C. M.; Kramer, 
M. L.; Barker, R. H.; Skerlj, R.; Sidhu, A. B.; Deng, X.; Celatka, C.; Cortese, J. F.; Guerrero Bravo, J. E.; Crespo Llado, K. N.; Serrano, A. E.; Angulo-Barturen, I.; Jiménez-Díaz, M. B.; Viera, S.; Garuti, H.; Wittlin, S.; Papastogiannidis, P.; Lin, J. W.; Janse, C. J.; Khan, S. M.; Duraisingh, M.; Coleman, B.; Goldsmith, E. J.; Phillips, M. A.; Munoz, B.; Wirth, D. F.; Klinger, J. D.; Wiegand, R.; Sybertz, E. J. Biol. Chem. 2010, 285, 33054-33064.

8. (a) Heikkilä, T.; Thirumalairajan, S.; Davies, M.; Parsons, M. R.; McConkey, G. A.; Fishwick, C. W. G.; Johnson, A. P. Bioorg. Med. Chem. Lett. 2006, 16, 88-92; (b) Davies, M.; Heikkilä, T.; McConkey, G.A.; Fishwick, C. W. G.; Parsons, M. R.; Johnson, A.P. J. Med. Chem. 2009, 52, 2683-2693.

9. (a) Hurt, D. E.; Widom, J.; Clardy, J.; Acta Crystallogr., Sect. D: Biol. Crystallogr. 2006, 62, 312-23; (b) Deng, X.; Gujjar, R.; El Mazouni, F.; Kaminsky, W.; Malmquist, N. A.; Goldsmith, E. J.; Rathod, P. K.; Phillips, M. A. J. Biol. Chem. 2009, 284, 26999-27009.

10. (a) Heikkilä, T.; Ramsey, C.; Davies, M.; Galtier, C.; Stead, A. M. W.; Johnson, A. P.; Fishwick, C. W. G.; Boa, A. N.; McConkey, G. A. J. Med. Chem. 2007, 50, 186-191; (b) Cowen, D.; Bedingfield, P.; McConkey, G. A.; Fishwick, C. W. G.; Johnson, A. P. Bioorg. Med. Chem. Lett. 2010, 20, 1284-1287.

11. Fritzson, I.; Bedingfield, P. T. P.; Sundin, A. P.; McConkey, G.; Nilsson, U. J. Med. Chem. Comm. 2011, 2, 895-898.

12. (a) Coteron, J. M.; Marco, M.; Esquivias, J.; Deng, X.; White, K. L.; White, J.; Koltun, M.; El Mazouni, F.; Kokkonda, S.; Katneni, K.; Bhamidipati, R.; Shackleford, D. M.; Angulo-Barturen, I.; Ferrer, S. B.; Jiménez-Díaz, M. B.; Gamo, F. J.; Goldsmith, E. J.; Charman, W. N.; Bathurst, I.; Floyd, D.; Matthews, D.; Burrows, J. N.; Rathod, P. K.; Charman, SA.; Phillips, M. A. J. Med. Chem. 2011, 54, 5540-5561; (b) Gujjar, R.; Marwaha, A.; El Mazouni, F.; White, J.; White, K. L.; Creason, S.; Shackleford, D. M.; Baldwin, J.; Charman, W. N.; Buckner, F. S.; Charman, S.; 
Rathod, P. K.; Phillips, M. A. J. Med. Chem. 2009, 52, 1864-1872; (c) Phillips, M. A.; Gujjar, R.; Malmquist, N. A.; White, J.; El Mazouni, F.; Baldwin, J.; Rathod, P. K. J. Med. Chem. 2008, $51,3649-3653$.

13. (a) Ashley, E. Lancet Infect. Dis. 2017, dx.doi.org/10.1016/S1473-3099(17)30172-X; (b) McCarthy, J. S.; Lotharius, J.; Rückle, T.; Chalon, S.; Phillips, M. A.; Elliott, S.; Sekuloski, S.; Griffin, P.; Ng, C. L.; Fidock, D. A.; Marquart, L.; Williams, N. S.; Gobeau, N.; Bebrevska, L.; Rosario, M.; Marsh, K.; Möhrle, J. J. Lancet Infect. Dis. 2017, dx.doi.org/10.1016/S14733099(17)30172-X; (c) Sulyok, M. ; Rückle, T.; Roth, A.; Mürbeth, R. E.; Chalon, S.; Kerr, N.; Schnieper Samec, S.; Gobeau, N.; Lamsfus Calle, C.; Ibáñez, J.; Sulyok, Z.; Held, J.; Gebru, T.; Granados, P.; Brückner, S.; Nguetse, C.; Mengue, J.; Lalremruata, A.; Sim, K. L.; Hoffman, S. L.; Möhrle, J. J.; Kremsner, P. G.; Mordmüller, B., Lancet Infect. Dis. 2017, http://dx.doi.org/10.1016/S1473-3099(17)30139-1.

14. Baumgartner, R.; Walloschek, M.; Kralik, M.; Gotschlich, A.; Tasler, S.; Mies, J.; Leban, J. J. Med. Chem. 2006, 49, 1239-1247.

15. Typical experimental procedure: Preparation of (E/Z)-ethyl 3-(9'-ethyl-9H-carbazol-3'ylamino)-2-nitroacrylate (2e). A mixture of ethyl nitroacetate (3.99 g, $30 \mathrm{mmol})$ and triethylorthoformate $\left(30 \mathrm{~cm}^{3}\right)$ in toluene $\left(40 \mathrm{~cm}^{3}\right)$ was heated under reflux in a nitrogen atmosphere for $2.5 \mathrm{~h}$. After cooling 3-amino-9-ethylcarbazole (5.00 g, $24 \mathrm{mmol})$ was added to this mixture, which was stirred for 10 minutes, to ensure thorough mixing, before being heated under reflux for a further period of 1 hour. The reaction mixture was then cooled and left to stand overnight. The resulting solid was collected by filtration and was washed carefully with toluene $\left(2 \times 20 \mathrm{~cm}^{3}\right)$. The resulting orange-red solid was recrystallised from ethanol to yield the title compound as bright red crystals $(4.63 \mathrm{~g}, 55 \%)$. A sample suitable for X-ray diffraction analysis was prepared by recrystallisation from ethyl acetate. ${ }^{1} \mathrm{H} \mathrm{NMR}\left(\mathrm{CDCl}_{3}, 400 \mathrm{MHz}\right)$ for this $1: 1$ 
mixture of geometric isomers, both chemical shifts are given when clearly resolved. $\delta 11.52$ [11.24] $(1 \mathrm{H}, \mathrm{bd}, J \sim 14.5[\sim 14.7] \mathrm{Hz},=\mathrm{CH}-\mathrm{NH}), 9.21[8.66](1 \mathrm{H}, \mathrm{d}, J 14.5[14.7] \mathrm{Hz},=\mathrm{CH}-\mathrm{NH})$, 8.12-8.09 (1H, m, ArH), 7.95 (1H, dd, J 8.8, $2.2 \mathrm{~Hz}$ ArH), 7.57-7.52 (1H, m, ArH), 7.47-7.43 $(2 \mathrm{H}, \mathrm{m}, \mathrm{ArH}), 7.37-7.28(2 \mathrm{H}, \mathrm{m}, \mathrm{ArH}), 4.45\left(2 \mathrm{H}, \mathrm{q}, J\right.$ 7.1 Hz, $\mathrm{OCH}_{2}$ or $\left.\mathrm{NCH}_{2}\right), 4.42-4.36(2 \mathrm{H}$, m, $\mathrm{NCH}_{2}$ or $\left.\mathrm{OCH}_{2}\right), 1.48-1.43\left(3 \mathrm{H}, \mathrm{m}, \mathrm{CH}_{2} \mathrm{CH}_{3}\right), 1.41\left(3 \mathrm{H}, \mathrm{t}, J \mathrm{~J} .1 \mathrm{~Hz}, \mathrm{CH}_{2} \mathrm{CH}_{3}\right) ;{ }^{13} \mathrm{C}-\mathrm{NMR}$ $\left(\mathrm{CDCl}_{3}, 100 \mathrm{MHz}\right) \delta 164.99$ [161.48], 149.82 [146.00], 140.73 [140.70], 138.60 [138.37], 130.07 [129.88], 126.86 [126.77], 123.74 [123.72], 122.09 [122.06], 120.71, 119.53 [119.45], 118.28 [117.38], 117.00 [116.69], 110.60 [110.06], 109.58 [109.54], 108.99 [108.94], 61.52 [61.35], 37.79 [37.76], 14.37 [14.28], 13.78; MS (ESI) $\mathrm{m} / \mathrm{z} 354.1449,\left[\mathrm{C}_{19} \mathrm{H}_{19} \mathrm{~N}_{3} \mathrm{O}_{4}+\mathrm{H}\right]^{+}$requires 354.1448. Also observed were $724.3085\left(\mathrm{M}_{2} \mathrm{NH}_{4}{ }^{+}\right.$, calc. 724.3089$)$ and $1077.4459\left(\mathrm{M}_{3} \mathrm{NH}_{4}{ }^{+}\right.$, calc. 1077.4465); Anal. $\left(\mathrm{C}_{19} \mathrm{H}_{19} \mathrm{~N}_{3} \mathrm{O}_{4}\right)$ Found: $\mathrm{C}, 64.74 \%$;, $6.41 \%$;, $11.70 \%$. Calcd. C, $64.58 \%$; H, $5.42 \%$; N, $11.89 \%$. In a similar fashion (E/Z)-ethyl 3-(dibenzothiophen-2'ylaminomethylene)-2-nitroacrylate (3e) was prepared from ethyl nitroacetate $(0.45 \mathrm{~g}, 7.5 \mathrm{~mol})$ and 3-aminodibenzothiophene $(0.5 \mathrm{~g}, 2.5 \mathrm{~mol})$ to give the title compound as a lemon yellow, crystalline solid $(0.61 \mathrm{~g}, 71 \%) .{ }^{1} \mathrm{H} \mathrm{NMR}\left(\mathrm{CDCl}_{3}, 400 \mathrm{MHz}\right) \delta 11.37[11.18](1 \mathrm{H}, \mathrm{bd}, J \sim 14.3$ $[\sim 14.3] \mathrm{Hz},=\mathrm{CH}-\mathrm{NH}), 9.22[8.68](1 \mathrm{H}, \mathrm{d}, J 14.3[14.3] \mathrm{Hz},=\mathrm{CH}-\mathrm{NH}), 8.20-8.16(1 \mathrm{H}, \mathrm{m}, \mathrm{ArH})$, 7.99 (1H, dd, J 8.5, 2.4 Hz ArH), 7.93 (1H, d, J 8.5 Hz, ArH), 7.91-7.86 (2H, m, ArH), 7.56$7.51(2 \mathrm{H}, \mathrm{m}, \mathrm{ArH}), 7.39-7.33(1 \mathrm{H}, \mathrm{m}, \mathrm{ArH}), 4.46$ [4.39] (2H, q, J 7.2 Hz, OCH$), 1.45$ [1.41] $\left(3 \mathrm{H}, \mathrm{t}, J 7.2 \mathrm{~Hz}, \mathrm{CH}_{2} \mathrm{CH}_{3}\right) ;{ }^{13} \mathrm{C}-\mathrm{NMR}\left(d_{6}-\mathrm{DMSO}, 100 \mathrm{MHz}\right.$, at $\left.24.1{ }^{\circ} \mathrm{C}\right) 139.5,136.6,136.1$, 136.0, 134.6, 127.6, 124.9, 123.9, 123.2, 122.4, 119.3, 112.5 (broad), 60.8, 14.2; MS (EI) m/z $342\left(\mathrm{M}^{+}\right), 326,252,235,222,183,139 ;$ Anal. $\left(\mathrm{C}_{17} \mathrm{H}_{14} \mathrm{~N}_{2} \mathrm{O}_{4} \mathrm{~S}\right)$ Found: $\mathrm{C}, 59.48 \%$; $\mathrm{H}, 4.25 \%$; , 8.20\%. Calcd. C, $59.64 \% ; \mathrm{H}, 4.12 \%$; N, $8.18 \%$.

16. Reaction of $o$-toluidine with $\mathbf{6 a}$ gave a product with an NMR indicating a 1:9 ratio of doubled signals [ $\delta 7.45 \mathrm{ppm}$ vs $10.89 \mathrm{ppm}$ for the $\mathrm{NH}$, and $\delta 8.36 \mathrm{ppm}$ vs $7.87 \mathrm{ppm}$ for the $\mathrm{CH}]$. This 
however is due to the presence of rotamers about the N-Ar bond due to the ortho methyl group. Crystallization of this derivative is induced by cooling a hexane solution, rather than dissolution in boiling ethanol, as used for $\mathbf{2} \mathbf{f}$ and $\mathbf{3 f}$. The heat presumably encourages any interconversion of isomers in the latter case.

17. CCDC 857094 contains the supplementary crystallographic data for the red crystalline form of (Z)-2e at $150 \mathrm{~K}$. These data can be obtained free of charge from the Cambridge Crystallographic Data Centre, 12 Union Road, Cambridge CB2 1EZ, UK; fax: (+44) 1223-336-033; e-mail: deposit@ccdc.cam.ac.uk or via http://www.ccdc.cam.ac.uk/conts/retrieving.html.

18. CCDC 1550062 contains the supplementary crystallographic data for the orange crystalline form of $2 \mathrm{e}$ at $150 \mathrm{~K}$. These data can be obtained free of charge from the Cambridge Crystallographic Data Centre, 12 Union Road, Cambridge CB2 1EZ, UK; fax: (+44) 1223-336-033; e-mail: deposit@ccdc.cam.ac.uk or via http://www.ccdc.cam.ac.uk/conts/retrieving.html. 


\section{Supplementary Information}

\section{Interconvertible geometric isomers of Plasmodium falciparum dihydroorotate dehydrogenase inhibitors exhibit multiple binding modes}

Glenn A. McConkeya, Paul T. P. Bedingfield ${ }^{\mathrm{a}}$, David R. Burrell ${ }^{\mathrm{b}}$, Nicholas C. Chambers ${ }^{\mathrm{b}}$, Fraser Cunningham $^{\mathrm{c}}$, Timothy J. Prior ${ }^{\mathrm{b}}$, Colin W.G. Fishwick ${ }^{\mathrm{c}}$, Andrew N. Boa ${ }^{\mathrm{b}^{*}}$

${ }^{a}$ School of Biology, Faculty of Biological Sciences, University of Leeds, Leeds LS2 9JT, UK

${ }^{b}$ School of Mathematics \& Physical Sciences, Faculty of Science and Engineering, University of Hull, Hull HU6 7RX, UK

${ }^{c}$ School of Chemistry, Faculty of Mathematics and Physical Sciences, University of Leeds, Leeds LS2 9JT, UK 
CCDC 857094 contains the supplementary crystallographic data for the red crystalline form of $(Z)-2 e$ at $150 \mathrm{~K}$. These data can be obtained free of charge from the Cambridge Crystallographic Data Centre, 12 Union Road, Cambridge CB2 1EZ, UK; fax: (+44) 1223-336-033; e-mail: deposit@ccdc.cam.ac.uk or via http://www.ccdc.cam.ac.uk/conts/retrieving.html.

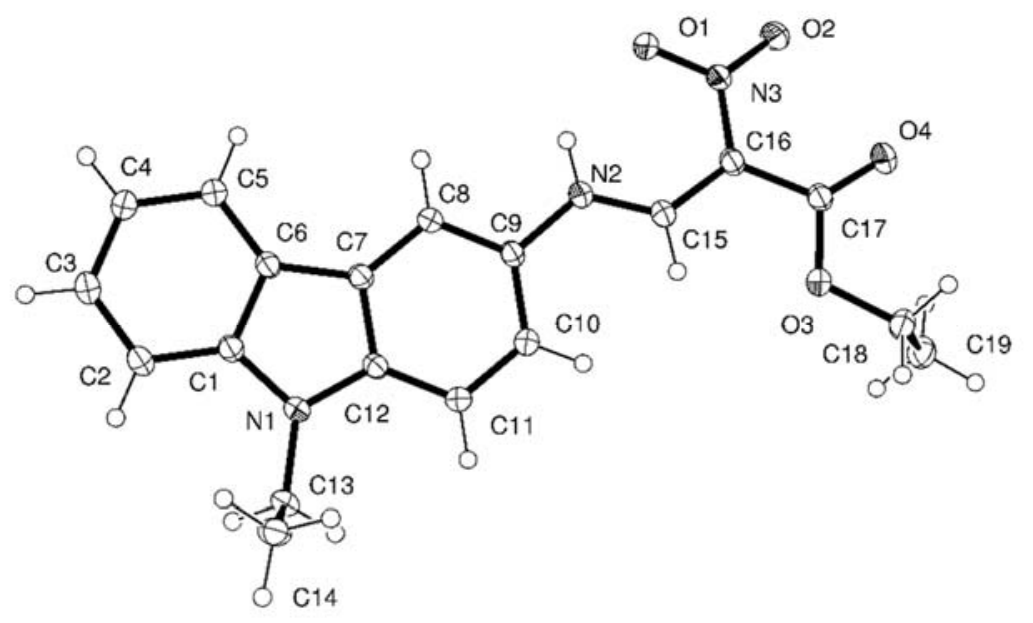

Table S1. Crystal data and structure refinement for (Z)-2e (red crystals)

Identification code

Empirical formula

Formula weight

Temperature

Wavelength

Crystal system

Space group

Unit cell dimensions

Volume

Z

Density (calculated)

Absorption coefficient shelx

C19 H19 N3 O4

353.38

120(2) K

$0.71073 \AA$

Triclinic

$\mathrm{P}-1$

$\mathrm{a}=8.7617(18) \AA \quad \alpha=87.020(16)^{\circ}$.

$\mathrm{b}=8.8742(18) \AA \quad \beta=71.107(15)^{\circ}$.

$\mathrm{c}=12.804(2) \AA \quad \gamma=61.257(14)^{\circ}$.

819.4(3) $\AA^{3}$

2

$1.432 \mathrm{Mg} / \mathrm{m}^{3}$

$0.102 \mathrm{~mm}^{-1}$ 
$\mathrm{F}(000)$

Crystal size

Theta range for data collection

Index ranges

Reflections collected

Independent reflections

Completeness to theta $=25.242^{\circ}$

Refinement method

Data / restraints / parameters

Goodness-of-fit on $\mathrm{F}^{2}$

Final $\mathrm{R}$ indices [I $>2 \operatorname{sigma}(\mathrm{I})]$

$\mathrm{R}$ indices (all data)

Extinction coefficient

Largest diff. peak and hole
372

$0.120 \times 0.120 \times 0.030 \mathrm{~mm}^{3}$

2.638 to $30.043^{\circ}$.

$-12 \leq \mathrm{h} \leq 11,-12 \leq \mathrm{k} \leq 10,-18 \leq 1 \leq 18$

8275

$4779[\mathrm{R}(\mathrm{int})=0.0513]$

$99.3 \%$

Full-matrix least-squares on $\mathrm{F}^{2}$

4779 / 0 / 237

1.002

$\mathrm{R} 1=0.0464, \mathrm{wR} 2=0.1215$

$\mathrm{R} 1=0.0759, \mathrm{wR} 2=0.1371$

none

0.270 and -0.306 e. $\AA^{-3}$ 
Table S2. Atomic coordinates $\left(\times 10^{4}\right)$ and equivalent isotropic displacement parameters $\left(\AA^{2} \times 10^{3}\right)$ for $(Z)-2 e$ (red crystals). $U(e q)$ is defined as one third of the trace of the orthogonalized $U^{i j}$ tensor.

\begin{tabular}{|c|c|c|c|c|}
\hline & $\mathrm{x}$ & $\mathrm{y}$ & $\mathrm{z}$ & $\mathrm{U}(\mathrm{eq})$ \\
\hline $\mathrm{N}(1)$ & $7438(2)$ & $6270(2)$ & $-1928(1)$ & $24(1)$ \\
\hline$C(1)$ & $8896(2)$ & $4945(2)$ & $-2738(1)$ & $22(1)$ \\
\hline$C(2)$ & $8862(2)$ & $4116(2)$ & $-3623(1)$ & $26(1)$ \\
\hline$C(3)$ & $10529(2)$ & $2771(2)$ & $-4302(1)$ & $28(1)$ \\
\hline$C(4)$ & $12188(2)$ & $2266(2)$ & $-4112(1)$ & $27(1)$ \\
\hline$C(5)$ & $12237(2)$ & $3108(2)$ & $-3250(1)$ & $24(1)$ \\
\hline$C(6)$ & $10572(2)$ & $4477(2)$ & $-2558(1)$ & $21(1)$ \\
\hline$C(7)$ & $10097(2)$ & $5634(2)$ & $-1616(1)$ & $21(1)$ \\
\hline$C(8)$ & $11136(2)$ & $5839(2)$ & $-1063(1)$ & $21(1)$ \\
\hline$C(9)$ & $10213(2)$ & $7101(2)$ & $-153(1)$ & $21(1)$ \\
\hline$C(10)$ & $8273(2)$ & $8115(2)$ & 239(1) & $24(1)$ \\
\hline $\mathrm{C}(11)$ & $7232(2)$ & $7927(2)$ & $-311(1)$ & $24(1)$ \\
\hline$C(12)$ & $8153(2)$ & $6709(2)$ & $-1251(1)$ & $22(1)$ \\
\hline$C(13)$ & $5534(2)$ & $7207(2)$ & $-1910(1)$ & $25(1)$ \\
\hline$C(14)$ & $5256(2)$ & $8549(2)$ & $-2716(1)$ & $30(1)$ \\
\hline $\mathrm{N}(2)$ & $11312(2)$ & $7266(2)$ & $396(1)$ & $23(1)$ \\
\hline$C(15)$ & $10713(2)$ & $8497(2)$ & $1200(1)$ & $22(1)$ \\
\hline$C(16)$ & $11643(2)$ & $8680(2)$ & $1840(1)$ & $23(1)$ \\
\hline $\mathrm{N}(3)$ & $13491(2)$ & $7423(2)$ & $1680(1)$ & $25(1)$ \\
\hline $\mathrm{O}(1)$ & $14338(1)$ & $6288(1)$ & $846(1)$ & $28(1)$ \\
\hline $\mathrm{O}(2)$ & $14255(2)$ & $7403(2)$ & $2341(1)$ & $42(1)$ \\
\hline$C(17)$ & $10680(2)$ & $10153(2)$ & 2731(1) & $24(1)$ \\
\hline $\mathrm{O}(3)$ & $8879(1)$ & $11120(1)$ & $2822(1)$ & $26(1)$ \\
\hline $\mathrm{O}(4)$ & $11362(2)$ & $10485(2)$ & $3297(1)$ & $35(1)$ \\
\hline$C(18)$ & $7786(2)$ & $12655(2)$ & $3641(1)$ & $28(1)$ \\
\hline$C(19)$ & $6932(2)$ & $12254(2)$ & $4761(1)$ & $33(1)$ \\
\hline
\end{tabular}


Table S3. Bond lengths $[\AA]$ and angles $\left[^{\circ}\right]$ for $(Z)-2 e$ (red crystals).

\begin{tabular}{|c|c|c|c|}
\hline $\mathrm{N}(1)-\mathrm{C}(1)$ & $1.3840(18)$ & $C(16)-C(17)$ & $1.4812(19)$ \\
\hline $\mathrm{N}(1)-\mathrm{C}(12)$ & $1.3841(17)$ & $\mathrm{N}(3)-\mathrm{O}(2)$ & $1.2326(16)$ \\
\hline $\mathrm{N}(1)-\mathrm{C}(13)$ & $1.4549(18)$ & $\mathrm{N}(3)-\mathrm{O}(1)$ & $1.2592(16)$ \\
\hline $\mathrm{C}(1)-\mathrm{C}(2)$ & $1.3975(19)$ & $\mathrm{C}(17)-\mathrm{O}(4)$ & $1.2007(17)$ \\
\hline$C(1)-C(6)$ & $1.4161(19)$ & $\mathrm{C}(17)-\mathrm{O}(3)$ & $1.3526(18)$ \\
\hline$C(2)-C(3)$ & $1.387(2)$ & $\mathrm{O}(3)-\mathrm{C}(18)$ & $1.4547(17)$ \\
\hline $\mathrm{C}(2)-\mathrm{H}(2)$ & 0.9500 & $\mathrm{C}(18)-\mathrm{C}(19)$ & $1.501(2)$ \\
\hline$C(3)-C(4)$ & $1.402(2)$ & $\mathrm{C}(18)-\mathrm{H}(18 \mathrm{~A})$ & 0.9900 \\
\hline $\mathrm{C}(3)-\mathrm{H}(3)$ & 0.9500 & $\mathrm{C}(18)-\mathrm{H}(18 \mathrm{~B})$ & 0.9900 \\
\hline$C(4)-C(5)$ & $1.3872(19)$ & $\mathrm{C}(19)-\mathrm{H}(19 \mathrm{~A})$ & 0.9800 \\
\hline $\mathrm{C}(4)-\mathrm{H}(4)$ & 0.9500 & C(19)-H(19B) & 0.9800 \\
\hline$C(5)-C(6)$ & $1.3996(19)$ & $\mathrm{C}(19)-\mathrm{H}(19 \mathrm{C})$ & 0.9800 \\
\hline $\mathrm{C}(5)-\mathrm{H}(5)$ & 0.9500 & & \\
\hline$C(6)-C(7)$ & $1.4407(18)$ & $\mathrm{C}(1)-\mathrm{N}(1)-\mathrm{C}(12)$ & $108.18(11)$ \\
\hline $\mathrm{C}(7)-\mathrm{C}(8)$ & $1.3973(18)$ & $\mathrm{C}(1)-\mathrm{N}(1)-\mathrm{C}(13)$ & $124.98(12)$ \\
\hline$C(7)-C(12)$ & $1.4133(19)$ & $\mathrm{C}(12)-\mathrm{N}(1)-\mathrm{C}(13)$ & $126.17(12)$ \\
\hline $\mathrm{C}(8)-\mathrm{C}(9)$ & $1.3858(19)$ & $\mathrm{N}(1)-\mathrm{C}(1)-\mathrm{C}(2)$ & $129.00(13)$ \\
\hline $\mathrm{C}(8)-\mathrm{H}(8)$ & 0.9500 & $\mathrm{~N}(1)-\mathrm{C}(1)-\mathrm{C}(6)$ & $109.36(12)$ \\
\hline$C(9)-C(10)$ & $1.4052(19)$ & $\mathrm{C}(2)-\mathrm{C}(1)-\mathrm{C}(6)$ & $121.63(13)$ \\
\hline $\mathrm{C}(9)-\mathrm{N}(2)$ & $1.4242(17)$ & $\mathrm{C}(3)-\mathrm{C}(2)-\mathrm{C}(1)$ & $117.54(13)$ \\
\hline $\mathrm{C}(10)-\mathrm{C}(11)$ & $1.3884(19)$ & $\mathrm{C}(3)-\mathrm{C}(2)-\mathrm{H}(2)$ & 121.2 \\
\hline $\mathrm{C}(10)-\mathrm{H}(10)$ & 0.9500 & $\mathrm{C}(1)-\mathrm{C}(2)-\mathrm{H}(2)$ & 121.2 \\
\hline $\mathrm{C}(11)-\mathrm{C}(12)$ & $1.3919(19)$ & $\mathrm{C}(2)-\mathrm{C}(3)-\mathrm{C}(4)$ & $121.25(13)$ \\
\hline $\mathrm{C}(11)-\mathrm{H}(11)$ & 0.9500 & $\mathrm{C}(2)-\mathrm{C}(3)-\mathrm{H}(3)$ & 119.4 \\
\hline$C(13)-C(14)$ & $1.516(2)$ & $\mathrm{C}(4)-\mathrm{C}(3)-\mathrm{H}(3)$ & 119.4 \\
\hline $\mathrm{C}(13)-\mathrm{H}(13 \mathrm{~A})$ & 0.9900 & $C(5)-C(4)-C(3)$ & $121.47(13)$ \\
\hline $\mathrm{C}(13)-\mathrm{H}(13 \mathrm{~B})$ & 0.9900 & $\mathrm{C}(5)-\mathrm{C}(4)-\mathrm{H}(4)$ & 119.3 \\
\hline $\mathrm{C}(14)-\mathrm{H}(14 \mathrm{~A})$ & 0.9800 & $\mathrm{C}(3)-\mathrm{C}(4)-\mathrm{H}(4)$ & 119.3 \\
\hline $\mathrm{C}(14)-\mathrm{H}(14 \mathrm{~B})$ & 0.9800 & $C(4)-C(5)-C(6)$ & $118.26(13)$ \\
\hline $\mathrm{C}(14)-\mathrm{H}(14 \mathrm{C})$ & 0.9800 & $\mathrm{C}(4)-\mathrm{C}(5)-\mathrm{H}(5)$ & 120.9 \\
\hline $\mathrm{N}(2)-\mathrm{C}(15)$ & $1.3201(17)$ & $\mathrm{C}(6)-\mathrm{C}(5)-\mathrm{H}(5)$ & 120.9 \\
\hline $\mathrm{N}(2)-\mathrm{H}(2 \mathrm{~A})$ & 0.8800 & $C(5)-C(6)-C(1)$ & $119.80(12)$ \\
\hline$C(15)-C(16)$ & $1.3914(18)$ & $C(5)-C(6)-C(7)$ & $133.75(13)$ \\
\hline $\mathrm{C}(15)-\mathrm{H}(15)$ & 0.9500 & $\mathrm{C}(1)-\mathrm{C}(6)-\mathrm{C}(7)$ & $106.44(12)$ \\
\hline $\mathrm{C}(16)-\mathrm{N}(3)$ & $1.4071(19)$ & $C(8)-C(7)-C(12)$ & $120.13(12)$ \\
\hline
\end{tabular}




\begin{tabular}{|c|c|c|c|}
\hline $\mathrm{C}(8)-\mathrm{C}(7)-\mathrm{C}(6)$ & $133.43(13)$ & $\mathrm{C}(15)-\mathrm{N}(2)-\mathrm{C}(9)$ & $125.65(12)$ \\
\hline$C(12)-C(7)-C(6)$ & $106.44(11)$ & $\mathrm{C}(15)-\mathrm{N}(2)-\mathrm{H}(2 \mathrm{~A})$ & 117.2 \\
\hline $\mathrm{C}(9)-\mathrm{C}(8)-\mathrm{C}(7)$ & $118.45(12)$ & $\mathrm{C}(9)-\mathrm{N}(2)-\mathrm{H}(2 \mathrm{~A})$ & 117.2 \\
\hline $\mathrm{C}(9)-\mathrm{C}(8)-\mathrm{H}(8)$ & 120.8 & $\mathrm{~N}(2)-\mathrm{C}(15)-\mathrm{C}(16)$ & $129.45(13)$ \\
\hline $\mathrm{C}(7)-\mathrm{C}(8)-\mathrm{H}(8)$ & 120.8 & $\mathrm{~N}(2)-\mathrm{C}(15)-\mathrm{H}(15)$ & 115.3 \\
\hline$C(8)-C(9)-C(10)$ & $121.32(12)$ & $\mathrm{C}(16)-\mathrm{C}(15)-\mathrm{H}(15)$ & 115.3 \\
\hline $\mathrm{C}(8)-\mathrm{C}(9)-\mathrm{N}(2)$ & $116.99(12)$ & $\mathrm{C}(15)-\mathrm{C}(16)-\mathrm{N}(3)$ & $120.25(12)$ \\
\hline $\mathrm{C}(10)-\mathrm{C}(9)-\mathrm{N}(2)$ & $121.63(12)$ & $C(15)-C(16)-C(17)$ & $120.60(13)$ \\
\hline$C(11)-C(10)-C(9)$ & $120.51(12)$ & $\mathrm{N}(3)-\mathrm{C}(16)-\mathrm{C}(17)$ & $119.09(12)$ \\
\hline $\mathrm{C}(11)-\mathrm{C}(10)-\mathrm{H}(10)$ & 119.7 & $\mathrm{O}(2)-\mathrm{N}(3)-\mathrm{O}(1)$ & $120.62(12)$ \\
\hline $\mathrm{C}(9)-\mathrm{C}(10)-\mathrm{H}(10)$ & 119.7 & $\mathrm{O}(2)-\mathrm{N}(3)-\mathrm{C}(16)$ & $121.59(12)$ \\
\hline $\mathrm{C}(10)-\mathrm{C}(11)-\mathrm{C}(12)$ & $118.54(13)$ & $\mathrm{O}(1)-\mathrm{N}(3)-\mathrm{C}(16)$ & $117.78(12)$ \\
\hline $\mathrm{C}(10)-\mathrm{C}(11)-\mathrm{H}(11)$ & 120.7 & $\mathrm{O}(4)-\mathrm{C}(17)-\mathrm{O}(3)$ & $123.53(13)$ \\
\hline $\mathrm{C}(12)-\mathrm{C}(11)-\mathrm{H}(11)$ & 120.7 & $\mathrm{O}(4)-\mathrm{C}(17)-\mathrm{C}(16)$ & $126.35(14)$ \\
\hline $\mathrm{N}(1)-\mathrm{C}(12)-\mathrm{C}(11)$ & $129.48(13)$ & $\mathrm{O}(3)-\mathrm{C}(17)-\mathrm{C}(16)$ & $110.11(12)$ \\
\hline $\mathrm{N}(1)-\mathrm{C}(12)-\mathrm{C}(7)$ & $109.51(12)$ & $\mathrm{C}(17)-\mathrm{O}(3)-\mathrm{C}(18)$ & $115.78(11)$ \\
\hline $\mathrm{C}(11)-\mathrm{C}(12)-\mathrm{C}(7)$ & $120.94(12)$ & $\mathrm{O}(3)-\mathrm{C}(18)-\mathrm{C}(19)$ & $111.28(13)$ \\
\hline $\mathrm{N}(1)-\mathrm{C}(13)-\mathrm{C}(14)$ & $112.21(13)$ & $\mathrm{O}(3)-\mathrm{C}(18)-\mathrm{H}(18 \mathrm{~A})$ & 109.4 \\
\hline $\mathrm{N}(1)-\mathrm{C}(13)-\mathrm{H}(13 \mathrm{~A})$ & 109.2 & $\mathrm{C}(19)-\mathrm{C}(18)-\mathrm{H}(18 \mathrm{~A})$ & 109.4 \\
\hline $\mathrm{C}(14)-\mathrm{C}(13)-\mathrm{H}(13 \mathrm{~A})$ & 109.2 & $\mathrm{O}(3)-\mathrm{C}(18)-\mathrm{H}(18 \mathrm{~B})$ & 109.4 \\
\hline $\mathrm{N}(1)-\mathrm{C}(13)-\mathrm{H}(13 \mathrm{~B})$ & 109.2 & $\mathrm{C}(19)-\mathrm{C}(18)-\mathrm{H}(18 \mathrm{~B})$ & 109.4 \\
\hline $\mathrm{C}(14)-\mathrm{C}(13)-\mathrm{H}(13 \mathrm{~B})$ & 109.2 & $\mathrm{H}(18 \mathrm{~A})-\mathrm{C}(18)-\mathrm{H}(18 \mathrm{~B})$ & 108.0 \\
\hline $\mathrm{H}(13 \mathrm{~A})-\mathrm{C}(13)-\mathrm{H}(13 \mathrm{~B})$ & 107.9 & $\mathrm{C}(18)-\mathrm{C}(19)-\mathrm{H}(19 \mathrm{~A})$ & 109.5 \\
\hline $\mathrm{C}(13)-\mathrm{C}(14)-\mathrm{H}(14 \mathrm{~A})$ & 109.5 & $\mathrm{C}(18)-\mathrm{C}(19)-\mathrm{H}(19 \mathrm{~B})$ & 109.5 \\
\hline $\mathrm{C}(13)-\mathrm{C}(14)-\mathrm{H}(14 \mathrm{~B})$ & 109.5 & $\mathrm{H}(19 \mathrm{~A})-\mathrm{C}(19)-\mathrm{H}(19 \mathrm{~B})$ & 109.5 \\
\hline $\mathrm{H}(14 \mathrm{~A})-\mathrm{C}(14)-\mathrm{H}(14 \mathrm{~B})$ & 109.5 & $\mathrm{C}(18)-\mathrm{C}(19)-\mathrm{H}(19 \mathrm{C})$ & 109.5 \\
\hline $\mathrm{C}(13)-\mathrm{C}(14)-\mathrm{H}(14 \mathrm{C})$ & 109.5 & $\mathrm{H}(19 \mathrm{~A})-\mathrm{C}(19)-\mathrm{H}(19 \mathrm{C})$ & 109.5 \\
\hline $\mathrm{H}(14 \mathrm{~A})-\mathrm{C}(14)-\mathrm{H}(14 \mathrm{C})$ & 109.5 & $\mathrm{H}(19 \mathrm{~B})-\mathrm{C}(19)-\mathrm{H}(19 \mathrm{C})$ & 109.5 \\
\hline $\mathrm{H}(14 \mathrm{~B})-\mathrm{C}(14)-\mathrm{H}(14 \mathrm{C})$ & 109.5 & & \\
\hline
\end{tabular}

Symmetry transformations used to generate equivalent atoms: 
Table S4. Anisotropic displacement parameters $\left(\AA^{2} \times 10^{3}\right)$ for (Z)-2e (red crystals). The anisotropic displacement factor exponent takes the form: $-2 \pi^{2}\left[\mathrm{~h}^{2} \mathrm{a}^{* 2} \mathrm{U}^{11}+\ldots+2 \mathrm{~h} \mathrm{k} \mathrm{a}^{*} \mathrm{~b}^{*} \mathrm{U}^{12}\right]$

\begin{tabular}{|c|c|c|c|c|c|c|}
\hline & $\mathrm{U}^{11}$ & $\mathrm{U}^{22}$ & $\mathrm{U}^{33}$ & $\mathrm{U}^{23}$ & $\mathrm{U}^{13}$ & $\mathrm{U}^{12}$ \\
\hline $\mathrm{N}(1)$ & $20(1)$ & $26(1)$ & $26(1)$ & $0(1)$ & $-11(1)$ & $-10(1)$ \\
\hline $\mathrm{C}(1)$ & $23(1)$ & $23(1)$ & $23(1)$ & $3(1)$ & $-10(1)$ & $-12(1)$ \\
\hline $\mathrm{C}(2)$ & $29(1)$ & $29(1)$ & $27(1)$ & $4(1)$ & $-14(1)$ & $-16(1)$ \\
\hline $\mathrm{C}(3)$ & $33(1)$ & $29(1)$ & $25(1)$ & 1(1) & $-12(1)$ & $-17(1)$ \\
\hline $\mathrm{C}(4)$ & $27(1)$ & $26(1)$ & $25(1)$ & $-2(1)$ & $-7(1)$ & $-12(1)$ \\
\hline$C(5)$ & $22(1)$ & $25(1)$ & $23(1)$ & $0(1)$ & $-7(1)$ & $-11(1)$ \\
\hline $\mathrm{C}(6)$ & $22(1)$ & $23(1)$ & $22(1)$ & $2(1)$ & $-9(1)$ & $-13(1)$ \\
\hline$C(7)$ & 21(1) & $22(1)$ & 21(1) & $3(1)$ & $-8(1)$ & $-11(1)$ \\
\hline $\mathrm{C}(8)$ & $20(1)$ & $22(1)$ & $22(1)$ & 2(1) & $-8(1)$ & $-10(1)$ \\
\hline $\mathrm{C}(9)$ & $23(1)$ & $23(1)$ & 21(1) & $2(1)$ & $-10(1)$ & $-12(1)$ \\
\hline$C(10)$ & $23(1)$ & $23(1)$ & $24(1)$ & $-1(1)$ & $-8(1)$ & $-10(1)$ \\
\hline $\mathrm{C}(11)$ & $19(1)$ & $23(1)$ & $27(1)$ & $-1(1)$ & $-8(1)$ & $-8(1)$ \\
\hline$C(12)$ & $21(1)$ & $23(1)$ & $23(1)$ & $3(1)$ & $-10(1)$ & $-11(1)$ \\
\hline $\mathrm{C}(13)$ & 21(1) & $30(1)$ & $29(1)$ & $2(1)$ & $-12(1)$ & $-13(1)$ \\
\hline$C(14)$ & $23(1)$ & $34(1)$ & $31(1)$ & $5(1)$ & $-12(1)$ & $-12(1)$ \\
\hline $\mathrm{N}(2)$ & $22(1)$ & $25(1)$ & $22(1)$ & 1(1) & $-8(1)$ & $-12(1)$ \\
\hline$C(15)$ & $24(1)$ & $24(1)$ & $22(1)$ & $2(1)$ & $-9(1)$ & $-13(1)$ \\
\hline$C(16)$ & $23(1)$ & $27(1)$ & $22(1)$ & 1(1) & $-8(1)$ & $-14(1)$ \\
\hline $\mathrm{N}(3)$ & $22(1)$ & $31(1)$ & $23(1)$ & $-1(1)$ & $-8(1)$ & $-14(1)$ \\
\hline $\mathrm{O}(1)$ & $23(1)$ & $31(1)$ & $28(1)$ & $-6(1)$ & $-7(1)$ & $-11(1)$ \\
\hline $\mathrm{O}(2)$ & $27(1)$ & $54(1)$ & $39(1)$ & $-13(1)$ & $-18(1)$ & $-10(1)$ \\
\hline$C(17)$ & $24(1)$ & $29(1)$ & $22(1)$ & $1(1)$ & $-7(1)$ & $-15(1)$ \\
\hline $\mathrm{O}(3)$ & $25(1)$ & $28(1)$ & $26(1)$ & $-4(1)$ & $-8(1)$ & $-12(1)$ \\
\hline $\mathrm{O}(4)$ & $31(1)$ & $42(1)$ & $33(1)$ & $-9(1)$ & $-12(1)$ & $-18(1)$ \\
\hline$C(18)$ & $29(1)$ & $25(1)$ & $27(1)$ & $-2(1)$ & $-8(1)$ & $-11(1)$ \\
\hline C(19) & $34(1)$ & $36(1)$ & $29(1)$ & $-2(1)$ & $-5(1)$ & $-20(1)$ \\
\hline
\end{tabular}


Table S5. Hydrogen coordinates $\left(\times 10^{4}\right)$ and isotropic displacement parameters $\left(\AA^{2} \times 10^{3}\right)$ for $(Z)-2 e$ (red crystals).

\begin{tabular}{|c|c|c|c|c|}
\hline & $\mathrm{x}$ & $\mathrm{y}$ & $\mathrm{z}$ & $\mathrm{U}(\mathrm{eq})$ \\
\hline $\mathrm{H}(2)$ & 7739 & 4461 & -3754 & 31 \\
\hline $\mathrm{H}(3)$ & 10547 & 2181 & -4907 & 33 \\
\hline $\mathrm{H}(4)$ & 13304 & 1325 & -4583 & 32 \\
\hline $\mathrm{H}(5)$ & 13370 & 2765 & -3133 & 28 \\
\hline $\mathrm{H}(8)$ & 12444 & 5131 & -1306 & 25 \\
\hline $\mathrm{H}(10)$ & 7668 & 8934 & 885 & 29 \\
\hline $\mathrm{H}(11)$ & 5921 & 8616 & -51 & 29 \\
\hline $\mathrm{H}(13 \mathrm{~A})$ & 4702 & 7788 & -1148 & 30 \\
\hline $\mathrm{H}(13 \mathrm{~B})$ & 5193 & 6373 & -2104 & 30 \\
\hline $\mathrm{H}(14 \mathrm{~A})$ & 6101 & 7983 & -3469 & 45 \\
\hline $\mathrm{H}(14 \mathrm{~B})$ & 5512 & 9422 & -2497 & 45 \\
\hline $\mathrm{H}(14 \mathrm{C})$ & 3974 & 9109 & -2702 & 45 \\
\hline $\mathrm{H}(2 \mathrm{~A})$ & 12493 & 6480 & 181 & 34 \\
\hline $\mathrm{H}(15)$ & 9464 & 9389 & 1365 & 27 \\
\hline $\mathrm{H}(18 \mathrm{~A})$ & 6795 & 13559 & 3392 & 34 \\
\hline $\mathrm{H}(18 \mathrm{~B})$ & 8588 & 13116 & 3699 & 34 \\
\hline H(19A) & 7913 & 11433 & 5037 & 50 \\
\hline $\mathrm{H}(19 \mathrm{~B})$ & 6188 & 11743 & 4697 & 50 \\
\hline $\mathrm{H}(19 \mathrm{C})$ & 6138 & 13324 & 5282 & 50 \\
\hline
\end{tabular}


CCDC 1550062 contains the supplementary crystallographic data for the orange crystalline form of $2 \mathrm{e}$ at $150 \mathrm{~K}$. These data can be obtained free of charge from the Cambridge Crystallographic Data Centre, 12 Union Road, Cambridge CB2 1EZ, UK; fax: (+44) 1223-336-033; e-mail: deposit@ccdc.cam.ac.uk or via http://www.ccdc.cam.ac.uk/conts/retrieving.html.

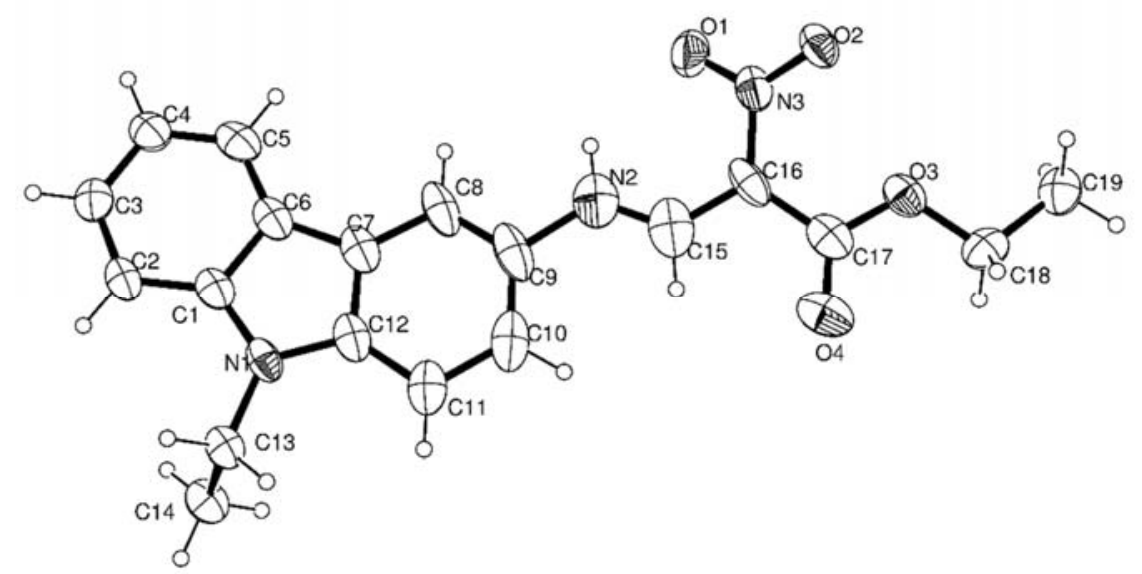

Table S6. Crystal data and structure refinement for $\mathbf{2 e}$ (orange crystal).

Identification code

Empirical formula

Formula weight

Temperature

Wavelength

Crystal system

Space group

Unit cell dimensions

Volume

Z

Density (calculated) shelx

C19 H19 N3 O4

353.37

150(2) K

$0.71073 \AA$

Triclinic

P - 1

$\mathrm{a}=8.123(2) \AA \quad \alpha=91.517(16)^{\circ}$.

$\mathrm{b}=8.2709(17) \AA \quad \beta=102.586(18)^{\circ}$.

$\mathrm{c}=13.834(3) \AA \quad \gamma=110.110(18)^{\circ}$.

$$
846.6(3) \AA^{3}
$$

2

$1.386 \mathrm{Mg} / \mathrm{m}^{3}$ 
Absorption coefficient

$\mathrm{F}(000)$

Crystal size

Theta range for data collection

Index ranges

Reflections collected

Independent reflections

Completeness to theta $=25.242^{\circ}$

Refinement method

Data / restraints / parameters

Goodness-of-fit on $\mathrm{F}^{2}$

Final $\mathrm{R}$ indices [I $>2 \operatorname{sigma}(\mathrm{I})]$

$\mathrm{R}$ indices (all data)

Extinction coefficient

Largest diff. peak and hole
$0.099 \mathrm{~mm}^{-1}$

372

$0.230 \times 0.140 \times 0.030 \mathrm{~mm}^{3}$

2.639 to $25.701^{\circ}$.

$-9 \leq \mathrm{h} \leq 9,-10 \leq \mathrm{k} \leq 9,-16 \leq 1 \leq 16$

7363

$3202[\mathrm{R}($ int $)=0.1891]$

$99.9 \%$

Full-matrix least-squares on $\mathrm{F}^{2}$

3202 / 0 / 235

1.020

$\mathrm{R} 1=0.1037, \mathrm{wR} 2=0.2756$

$\mathrm{R} 1=0.2014, \mathrm{wR} 2=0.3482$

none

1.169 and -0.357 e. $\AA^{-3}$ 
Table S7. Atomic coordinates ( $\times 10^{4}$ ) and equivalent isotropic displacement parameters $\left(\AA^{2} \times 10^{3}\right)$ for $2 \mathrm{e}$ (orange crystal). $U(e q)$ is defined as one third of the trace of the orthogonalized $U^{i j}$ tensor.

\begin{tabular}{|c|c|c|c|c|}
\hline & $\mathrm{x}$ & $\mathrm{y}$ & $\mathrm{z}$ & $\mathrm{U}(\mathrm{eq})$ \\
\hline $\mathrm{C}(1)$ & 4044(9) & $3717(7)$ & $8594(4)$ & $60(2)$ \\
\hline$C(2)$ & $3184(9)$ & $3231(8)$ & $9377(4)$ & $60(2)$ \\
\hline$C(3)$ & $1912(10)$ & $3928(8)$ & $9483(5)$ & $66(2)$ \\
\hline $\mathrm{C}(4)$ & $1465(10)$ & $5088(8)$ & $8850(5)$ & $69(2)$ \\
\hline $\mathrm{C}(5)$ & $2313(11)$ & $5554(8)$ & $8088(5)$ & $71(2)$ \\
\hline$C(6)$ & $3625(10)$ & 4912(7) & $7950(4)$ & $63(2)$ \\
\hline $\mathrm{C}(7)$ & $4804(10)$ & $5180(8)$ & $7279(4)$ & $68(2)$ \\
\hline $\mathrm{C}(8)$ & $5062(12)$ & $6246(8)$ & $6525(5)$ & $80(2)$ \\
\hline $\mathrm{C}(9)$ & $6317(13)$ & 6298(9) & $6041(5)$ & $88(3)$ \\
\hline $\mathrm{C}(10)$ & $7348(11)$ & $5213(10)$ & $6243(5)$ & $87(3)$ \\
\hline $\mathrm{C}(11)$ & $7137(10)$ & 4070(9) & $7010(5)$ & $77(2)$ \\
\hline $\mathrm{C}(12)$ & $5845(9)$ & 4104(8) & $7528(4)$ & $65(2)$ \\
\hline $\mathrm{C}(13)$ & $6129(9)$ & $2028(7)$ & $8823(4)$ & $60(2)$ \\
\hline$C(14)$ & $4969(9)$ & $156(8)$ & $8461(5)$ & $70(2)$ \\
\hline $\mathrm{C}(15)$ & $7619(12)$ & $7819(11)$ & $4745(6)$ & $92(3)$ \\
\hline$C(16)$ & $8059(10)$ & $9077(8)$ & $4119(5)$ & $71(2)$ \\
\hline $\mathrm{C}(17)$ & $9406(10)$ & $8984(8)$ & $3578(5)$ & $69(2)$ \\
\hline$C(18)$ & $10848(10)$ & $9885(9)$ & $2286(5)$ & $72(2)$ \\
\hline $\mathrm{C}(19)$ & $10808(10)$ & 11087(9) & $1503(5)$ & $76(2)$ \\
\hline $\mathrm{N}(1)$ & $5383(7)$ & $3255(6)$ & $8321(3)$ & $60(1)$ \\
\hline $\mathrm{N}(2)$ & $6573(10)$ & $7578(8)$ & $5295(5)$ & $89(2)$ \\
\hline $\mathrm{N}(3)$ & 7390(9) & $10469(7)$ & $4063(4)$ & $68(2)$ \\
\hline $\mathrm{O}(1)$ & $5949(9)$ & $10215(6)$ & $4311(4)$ & $95(2)$ \\
\hline $\mathrm{O}(2)$ & $8247(6)$ & $11864(5)$ & $3796(3)$ & $70(1)$ \\
\hline $\mathrm{O}(3)$ & $9595(6)$ & $10009(5)$ & 2866(3) & $67(1)$ \\
\hline $\mathrm{O}(4)$ & $10210(8)$ & $7986(6)$ & $3765(4)$ & $89(2)$ \\
\hline
\end{tabular}


Table S8. Bond lengths $[\AA]$ and angles $\left[^{\circ}\right]$ for $2 \mathbf{e}$ (orange crystal).

\begin{tabular}{|c|c|c|c|}
\hline $\mathrm{C}(1)-\mathrm{N}(1)$ & $1.388(9)$ & $C(16)-C(17)$ & $1.474(11)$ \\
\hline$C(1)-C(2)$ & $1.409(9)$ & $\mathrm{C}(17)-\mathrm{O}(4)$ & $1.218(8)$ \\
\hline$C(1)-C(6)$ & $1.426(9)$ & $\mathrm{C}(17)-\mathrm{O}(3)$ & $1.316(8)$ \\
\hline$C(2)-C(3)$ & $1.375(10)$ & $\mathrm{C}(18)-\mathrm{O}(3)$ & $1.454(8)$ \\
\hline $\mathrm{C}(2)-\mathrm{H}(2)$ & 0.9500 & $C(18)-C(19)$ & $1.492(10)$ \\
\hline $\mathrm{C}(3)-\mathrm{C}(4)$ & $1.402(9)$ & $\mathrm{C}(18)-\mathrm{H}(18 \mathrm{~A})$ & 0.9900 \\
\hline $\mathrm{C}(3)-\mathrm{H}(3)$ & 0.9500 & $\mathrm{C}(18)-\mathrm{H}(18 \mathrm{~B})$ & 0.9900 \\
\hline $\mathrm{C}(4)-\mathrm{C}(5)$ & $1.375(10)$ & C(19)-H(19A) & 0.9800 \\
\hline $\mathrm{C}(4)-\mathrm{H}(4)$ & 0.9500 & $\mathrm{C}(19)-\mathrm{H}(19 \mathrm{~B})$ & 0.9800 \\
\hline$C(5)-C(6)$ & $1.388(10)$ & $\mathrm{C}(19)-\mathrm{H}(19 \mathrm{C})$ & 0.9800 \\
\hline $\mathrm{C}(5)-\mathrm{H}(5)$ & 0.9500 & $\mathrm{~N}(2)-\mathrm{H}(2 \mathrm{~A})$ & 0.8800 \\
\hline$C(6)-C(7)$ & $1.442(10)$ & $\mathrm{N}(3)-\mathrm{O}(2)$ & $1.239(6)$ \\
\hline$C(7)-C(8)$ & $1.388(9)$ & $\mathrm{N}(3)-\mathrm{O}(1)$ & $1.242(8)$ \\
\hline$C(7)-C(12)$ & $1.426(10)$ & & \\
\hline $\mathrm{C}(8)-\mathrm{C}(9)$ & $1.326(12)$ & $\mathrm{N}(1)-\mathrm{C}(1)-\mathrm{C}(2)$ & $130.3(6)$ \\
\hline $\mathrm{C}(8)-\mathrm{H}(8)$ & 0.9500 & $\mathrm{~N}(1)-\mathrm{C}(1)-\mathrm{C}(6)$ & 108.9(6) \\
\hline$C(9)-C(10)$ & $1.419(13)$ & $\mathrm{C}(2)-\mathrm{C}(1)-\mathrm{C}(6)$ & $120.8(7)$ \\
\hline $\mathrm{C}(9)-\mathrm{N}(2)$ & $1.493(10)$ & $\mathrm{C}(3)-\mathrm{C}(2)-\mathrm{C}(1)$ & 117.6(6) \\
\hline$C(10)-C(11)$ & $1.439(11)$ & $\mathrm{C}(3)-\mathrm{C}(2)-\mathrm{H}(2)$ & 121.2 \\
\hline $\mathrm{C}(10)-\mathrm{H}(10)$ & 0.9500 & $\mathrm{C}(1)-\mathrm{C}(2)-\mathrm{H}(2)$ & 121.2 \\
\hline$C(11)-C(12)$ & $1.401(10)$ & $C(2)-C(3)-C(4)$ & $122.5(6)$ \\
\hline $\mathrm{C}(11)-\mathrm{H}(11)$ & 0.9500 & $\mathrm{C}(2)-\mathrm{C}(3)-\mathrm{H}(3)$ & 118.7 \\
\hline $\mathrm{C}(12)-\mathrm{N}(1)$ & $1.370(8)$ & $\mathrm{C}(4)-\mathrm{C}(3)-\mathrm{H}(3)$ & 118.7 \\
\hline $\mathrm{C}(13)-\mathrm{N}(1)$ & $1.468(8)$ & $C(5)-C(4)-C(3)$ & $119.5(7)$ \\
\hline C(13)-C(14) & $1.512(8)$ & $\mathrm{C}(5)-\mathrm{C}(4)-\mathrm{H}(4)$ & 120.3 \\
\hline $\mathrm{C}(13)-\mathrm{H}(13 \mathrm{~A})$ & 0.9900 & $\mathrm{C}(3)-\mathrm{C}(4)-\mathrm{H}(4)$ & 120.3 \\
\hline $\mathrm{C}(13)-\mathrm{H}(13 \mathrm{~B})$ & 0.9900 & $\mathrm{C}(4)-\mathrm{C}(5)-\mathrm{C}(6)$ & $120.7(6)$ \\
\hline $\mathrm{C}(14)-\mathrm{H}(14 \mathrm{~A})$ & 0.9800 & $\mathrm{C}(4)-\mathrm{C}(5)-\mathrm{H}(5)$ & 119.6 \\
\hline $\mathrm{C}(14)-\mathrm{H}(14 \mathrm{~B})$ & 0.9800 & $\mathrm{C}(6)-\mathrm{C}(5)-\mathrm{H}(5)$ & 119.6 \\
\hline $\mathrm{C}(14)-\mathrm{H}(14 \mathrm{C})$ & 0.9800 & $C(5)-C(6)-C(1)$ & $118.9(6)$ \\
\hline $\mathrm{C}(15)-\mathrm{N}(2)$ & $1.229(10)$ & $C(5)-C(6)-C(7)$ & $135.0(6)$ \\
\hline$C(15)-C(16)$ & $1.374(10)$ & $\mathrm{C}(1)-\mathrm{C}(6)-\mathrm{C}(7)$ & 106.0(6) \\
\hline $\mathrm{C}(15)-\mathrm{H}(15)$ & 0.9500 & $C(8)-C(7)-C(12)$ & $120.9(7)$ \\
\hline $\mathrm{C}(16)-\mathrm{N}(3)$ & $1.430(9)$ & $C(8)-C(7)-C(6)$ & $132.3(8)$ \\
\hline
\end{tabular}




\begin{tabular}{|c|c|c|c|}
\hline$C(12)-C(7)-C(6)$ & $106.8(5)$ & $\mathrm{O}(3)-\mathrm{C}(17)-\mathrm{C}(16)$ & $114.3(6)$ \\
\hline $\mathrm{C}(9)-\mathrm{C}(8)-\mathrm{C}(7)$ & $119.9(8)$ & $\mathrm{O}(3)-\mathrm{C}(18)-\mathrm{C}(19)$ & $107.1(6)$ \\
\hline $\mathrm{C}(9)-\mathrm{C}(8)-\mathrm{H}(8)$ & 120.1 & $\mathrm{O}(3)-\mathrm{C}(18)-\mathrm{H}(18 \mathrm{~A})$ & 110.3 \\
\hline $\mathrm{C}(7)-\mathrm{C}(8)-\mathrm{H}(8)$ & 120.1 & $\mathrm{C}(19)-\mathrm{C}(18)-\mathrm{H}(18 \mathrm{~A})$ & 110.3 \\
\hline$C(8)-C(9)-C(10)$ & $121.2(7)$ & $\mathrm{O}(3)-\mathrm{C}(18)-\mathrm{H}(18 \mathrm{~B})$ & 110.3 \\
\hline $\mathrm{C}(8)-\mathrm{C}(9)-\mathrm{N}(2)$ & $115.6(9)$ & $\mathrm{C}(19)-\mathrm{C}(18)-\mathrm{H}(18 \mathrm{~B})$ & 110.3 \\
\hline $\mathrm{C}(10)-\mathrm{C}(9)-\mathrm{N}(2)$ & $123.2(9)$ & $\mathrm{H}(18 \mathrm{~A})-\mathrm{C}(18)-\mathrm{H}(18 \mathrm{~B})$ & 108.5 \\
\hline $\mathrm{C}(9)-\mathrm{C}(10)-\mathrm{C}(11)$ & $121.6(8)$ & C(18)-C(19)-H(19A) & 109.5 \\
\hline $\mathrm{C}(9)-\mathrm{C}(10)-\mathrm{H}(10)$ & 119.2 & $\mathrm{C}(18)-\mathrm{C}(19)-\mathrm{H}(19 \mathrm{~B})$ & 109.5 \\
\hline $\mathrm{C}(11)-\mathrm{C}(10)-\mathrm{H}(10)$ & 119.2 & H(19A)-C(19)-H(19B) & 109.5 \\
\hline$C(12)-C(11)-C(10)$ & $115.3(8)$ & $\mathrm{C}(18)-\mathrm{C}(19)-\mathrm{H}(19 \mathrm{C})$ & 109.5 \\
\hline $\mathrm{C}(12)-\mathrm{C}(11)-\mathrm{H}(11)$ & 122.3 & H(19A)-C(19)-H(19C) & 109.5 \\
\hline $\mathrm{C}(10)-\mathrm{C}(11)-\mathrm{H}(11)$ & 122.3 & H(19B)-C(19)-H(19C) & 109.5 \\
\hline $\mathrm{N}(1)-\mathrm{C}(12)-\mathrm{C}(11)$ & $130.0(7)$ & $\mathrm{C}(12)-\mathrm{N}(1)-\mathrm{C}(1)$ & $109.3(5)$ \\
\hline $\mathrm{N}(1)-\mathrm{C}(12)-\mathrm{C}(7)$ & $108.9(6)$ & $\mathrm{C}(12)-\mathrm{N}(1)-\mathrm{C}(13)$ & $127.2(6)$ \\
\hline$C(11)-C(12)-C(7)$ & $121.0(6)$ & $\mathrm{C}(1)-\mathrm{N}(1)-\mathrm{C}(13)$ & $123.5(5)$ \\
\hline N(1)-C(13)-C(14) & $113.1(5)$ & $\mathrm{C}(15)-\mathrm{N}(2)-\mathrm{C}(9)$ & $126.9(9)$ \\
\hline $\mathrm{N}(1)-\mathrm{C}(13)-\mathrm{H}(13 \mathrm{~A})$ & 109.0 & $\mathrm{C}(15)-\mathrm{N}(2)-\mathrm{H}(2 \mathrm{~A})$ & 116.6 \\
\hline $\mathrm{C}(14)-\mathrm{C}(13)-\mathrm{H}(13 \mathrm{~A})$ & 109.0 & $\mathrm{C}(9)-\mathrm{N}(2)-\mathrm{H}(2 \mathrm{~A})$ & 116.6 \\
\hline N(1)-C(13)-H(13B) & 109.0 & $\mathrm{O}(2)-\mathrm{N}(3)-\mathrm{O}(1)$ & $122.6(6)$ \\
\hline $\mathrm{C}(14)-\mathrm{C}(13)-\mathrm{H}(13 \mathrm{~B})$ & 109.0 & $\mathrm{O}(2)-\mathrm{N}(3)-\mathrm{C}(16)$ & $120.5(6)$ \\
\hline $\mathrm{H}(13 \mathrm{~A})-\mathrm{C}(13)-\mathrm{H}(13 \mathrm{~B})$ & 107.8 & $\mathrm{O}(1)-\mathrm{N}(3)-\mathrm{C}(16)$ & $116.9(6)$ \\
\hline $\mathrm{C}(13)-\mathrm{C}(14)-\mathrm{H}(14 \mathrm{~A})$ & 109.5 & $\mathrm{C}(17)-\mathrm{O}(3)-\mathrm{C}(18)$ & $115.7(6)$ \\
\hline $\mathrm{C}(13)-\mathrm{C}(14)-\mathrm{H}(14 \mathrm{~B})$ & 109.5 & & \\
\hline $\mathrm{H}(14 \mathrm{~A})-\mathrm{C}(14)-\mathrm{H}(14 \mathrm{~B})$ & 109.5 & & \\
\hline $\mathrm{C}(13)-\mathrm{C}(14)-\mathrm{H}(14 \mathrm{C})$ & 109.5 & & \\
\hline $\mathrm{H}(14 \mathrm{~A})-\mathrm{C}(14)-\mathrm{H}(14 \mathrm{C})$ & 109.5 & & \\
\hline $\mathrm{H}(14 \mathrm{~B})-\mathrm{C}(14)-\mathrm{H}(14 \mathrm{C})$ & 109.5 & & \\
\hline$N(2)-C(15)-C(16)$ & $130.0(10)$ & & \\
\hline $\mathrm{N}(2)-\mathrm{C}(15)-\mathrm{H}(15)$ & 115.0 & & \\
\hline$C(16)-C(15)-H(15)$ & 115.0 & & \\
\hline $\mathrm{C}(15)-\mathrm{C}(16)-\mathrm{N}(3)$ & $122.5(8)$ & & \\
\hline $\mathrm{C}(15)-\mathrm{C}(16)-\mathrm{C}(17)$ & $115.2(8)$ & & \\
\hline $\mathrm{N}(3)-\mathrm{C}(16)-\mathrm{C}(17)$ & $122.1(6)$ & & \\
\hline $\mathrm{O}(4)-\mathrm{C}(17)-\mathrm{O}(3)$ & $124.0(8)$ & & \\
\hline $\mathrm{O}(4)-\mathrm{C}(17)-\mathrm{C}(16)$ & $121.6(6)$ & & \\
\hline
\end{tabular}


Symmetry transformations used to generate equivalent atoms: 
Table S9. Anisotropic displacement parameters $\left(\AA^{2} \times 10^{3}\right)$ for $2 \mathbf{e}$ (orange crystal). The anisotropic displacement factor exponent takes the form: $-2 \pi^{2}\left[h^{2} a^{* 2} U^{11}+\ldots+2 h k a^{*} b^{*} U^{12}\right]$

\begin{tabular}{|c|c|c|c|c|c|c|}
\hline & $\mathrm{U}^{11}$ & $\mathrm{U}^{22}$ & $\mathrm{U}^{33}$ & $\mathrm{U}^{23}$ & $\mathrm{U}^{13}$ & $\mathrm{U}^{12}$ \\
\hline $\mathrm{C}(1)$ & 70(4) & $39(3)$ & $52(3)$ & $-1(3)$ & $5(3)$ & $2(3)$ \\
\hline$C(2)$ & $70(4)$ & $48(3)$ & $46(3)$ & $5(3)$ & $6(3)$ & 4(3) \\
\hline$C(3)$ & 72(4) & $55(3)$ & $57(3)$ & $-4(3)$ & $15(3)$ & $8(3)$ \\
\hline $\mathrm{C}(4)$ & $88(5)$ & $53(3)$ & $57(4)$ & $-3(3)$ & $7(4)$ & $22(3)$ \\
\hline$C(5)$ & $93(5)$ & $40(3)$ & $58(4)$ & $-6(3)$ & $-6(4)$ & $13(3)$ \\
\hline$C(6)$ & $80(5)$ & $37(3)$ & $46(3)$ & $-3(2)$ & $-1(3)$ & $0(3)$ \\
\hline$C(7)$ & $86(5)$ & $43(3)$ & $45(3)$ & $-4(3)$ & $1(3)$ & $-4(3)$ \\
\hline$C(8)$ & $104(6)$ & $44(3)$ & $48(3)$ & $2(3)$ & $6(4)$ & $-20(3)$ \\
\hline $\mathrm{C}(9)$ & $112(7)$ & $53(4)$ & $52(4)$ & $5(3)$ & $5(4)$ & $-19(4)$ \\
\hline$C(10)$ & $83(5)$ & $79(5)$ & $59(4)$ & $-15(4)$ & $23(4)$ & $-23(4)$ \\
\hline $\mathrm{C}(11)$ & $76(5)$ & $72(4)$ & $54(4)$ & $-8(3)$ & $15(3)$ & $-6(3)$ \\
\hline$C(12)$ & $70(4)$ & $49(3)$ & $48(3)$ & $-1(3)$ & $6(3)$ & $-7(3)$ \\
\hline$C(13)$ & $62(4)$ & $51(3)$ & $54(3)$ & $5(3)$ & $6(3)$ & $10(3)$ \\
\hline$C(14)$ & 66(4) & $51(3)$ & 74(4) & $5(3)$ & $6(3)$ & $5(3)$ \\
\hline$C(15)$ & $91(6)$ & $78(5)$ & 61(4) & $-17(4)$ & 4(4) & $-16(4)$ \\
\hline$C(16)$ & $95(5)$ & $42(3)$ & $46(3)$ & $8(3)$ & $-3(3)$ & $-2(3)$ \\
\hline$C(17)$ & $78(5)$ & $46(3)$ & $56(4)$ & $-7(3)$ & $-6(3)$ & $3(3)$ \\
\hline$C(18)$ & $72(5)$ & $61(4)$ & 72(4) & $-18(3)$ & $12(4)$ & $17(3)$ \\
\hline$C(19)$ & $79(5)$ & $77(4)$ & $63(4)$ & $-6(4)$ & $18(4)$ & $15(4)$ \\
\hline $\mathrm{N}(1)$ & $69(3)$ & $45(2)$ & 49(3) & $10(2)$ & $7(2)$ & $3(2)$ \\
\hline $\mathrm{N}(2)$ & $90(5)$ & 74(4) & $72(4)$ & $-13(3)$ & $12(4)$ & $-4(3)$ \\
\hline $\mathrm{N}(3)$ & $88(4)$ & $49(3)$ & $52(3)$ & $-2(2)$ & $20(3)$ & $4(3)$ \\
\hline $\mathrm{O}(1)$ & $116(5)$ & $67(3)$ & $108(4)$ & $8(3)$ & $68(4)$ & $17(3)$ \\
\hline $\mathrm{O}(2)$ & $85(3)$ & $48(2)$ & $64(3)$ & 11(2) & $20(2)$ & $8(2)$ \\
\hline $\mathrm{O}(3)$ & $75(3)$ & $49(2)$ & 61(2) & $3(2)$ & $6(2)$ & $10(2)$ \\
\hline $\mathrm{O}(4)$ & $110(4)$ & $62(3)$ & 74(3) & $-5(2)$ & $-13(3)$ & $28(3)$ \\
\hline
\end{tabular}


Table S10. Hydrogen coordinates ( x $\left.10^{4}\right)$ and isotropic displacement parameters $\left(\AA^{2} \times 10^{3}\right)$ for $2 \mathrm{e}$ (orange crystal).

\begin{tabular}{|c|c|c|c|c|}
\hline & $\mathrm{x}$ & $\mathrm{y}$ & $\mathrm{z}$ & $\mathrm{U}(\mathrm{eq})$ \\
\hline $\mathrm{H}(2)$ & 3471 & 2450 & 9816 & 72 \\
\hline $\mathrm{H}(3)$ & 1314 & 3610 & 10006 & 79 \\
\hline $\mathrm{H}(4)$ & 583 & 5548 & 8947 & 83 \\
\hline $\mathrm{H}(5)$ & 1998 & 6325 & 7651 & 85 \\
\hline $\mathrm{H}(8)$ & 4341 & 6938 & 6356 & 96 \\
\hline $\mathrm{H}(10)$ & 8199 & 5242 & 5862 & 104 \\
\hline $\mathrm{H}(11)$ & 7825 & 3344 & 7154 & 92 \\
\hline $\mathrm{H}(13 \mathrm{~A})$ & 6259 & 2227 & 9549 & 72 \\
\hline $\mathrm{H}(13 \mathrm{~B})$ & 7349 & 2255 & 8712 & 72 \\
\hline $\mathrm{H}(14 \mathrm{~A})$ & 5530 & -601 & 8821 & 105 \\
\hline $\mathrm{H}(14 \mathrm{~B})$ & 3767 & -87 & 8583 & 105 \\
\hline $\mathrm{H}(14 \mathrm{C})$ & 4857 & -59 & 7746 & 105 \\
\hline $\mathrm{H}(15)$ & 8216 & 7011 & 4756 & 110 \\
\hline $\mathrm{H}(18 \mathrm{~A})$ & 10478 & 8683 & 1975 & 86 \\
\hline $\mathrm{H}(18 \mathrm{~B})$ & 12083 & 10222 & 2719 & 86 \\
\hline $\mathrm{H}(19 \mathrm{~A})$ & 11640 & 11040 & 1095 & 114 \\
\hline $\mathrm{H}(19 \mathrm{~B})$ & 9580 & 10740 & 1079 & 114 \\
\hline $\mathrm{H}(19 \mathrm{C})$ & 11177 & 12272 & 1821 & 114 \\
\hline $\mathrm{H}(2 \mathrm{~A})$ & 5905 & 8228 & 5242 & 107 \\
\hline
\end{tabular}


A portion of the orange powder, obtained from the mother liquors of the crystallisation of red (Z)-2e, was examined by X-ray powder diffraction using a PANAlytical Empyrean diffractometer operating with $\mathrm{Cu} K \alpha_{1}$ radiation. The powder was shown to be highly crystalline, but the diffraction pattern of the orange powder did not match that calculated from the structure of the red crystals (Figure S2) or orange crystals obtained (Figure S3). It was possible to index the powder diffraction pattern of the orange powder using a large triclinic cell with parameters shown below. The volume of this cell $\left(2506 \AA^{3}\right)$ is approximately three times that of the cell found for the red crystals. It seems reasonable that the orange sample contains (E)-2e and the tripling of the volume suggests that there are three molecules in the asymmetric unit, perhaps two of one isomeric form and one of the other.

$$
\begin{aligned}
& \mathrm{a}=15.93(3) \AA \\
& \mathrm{b}=15.03(3) \AA \\
& \mathrm{c}=13.07(3) \AA \\
& \alpha=70.08(17)^{\circ} \\
& \beta=106.64(14)^{\circ} \\
& \gamma=120.70(16)^{\circ}
\end{aligned}
$$

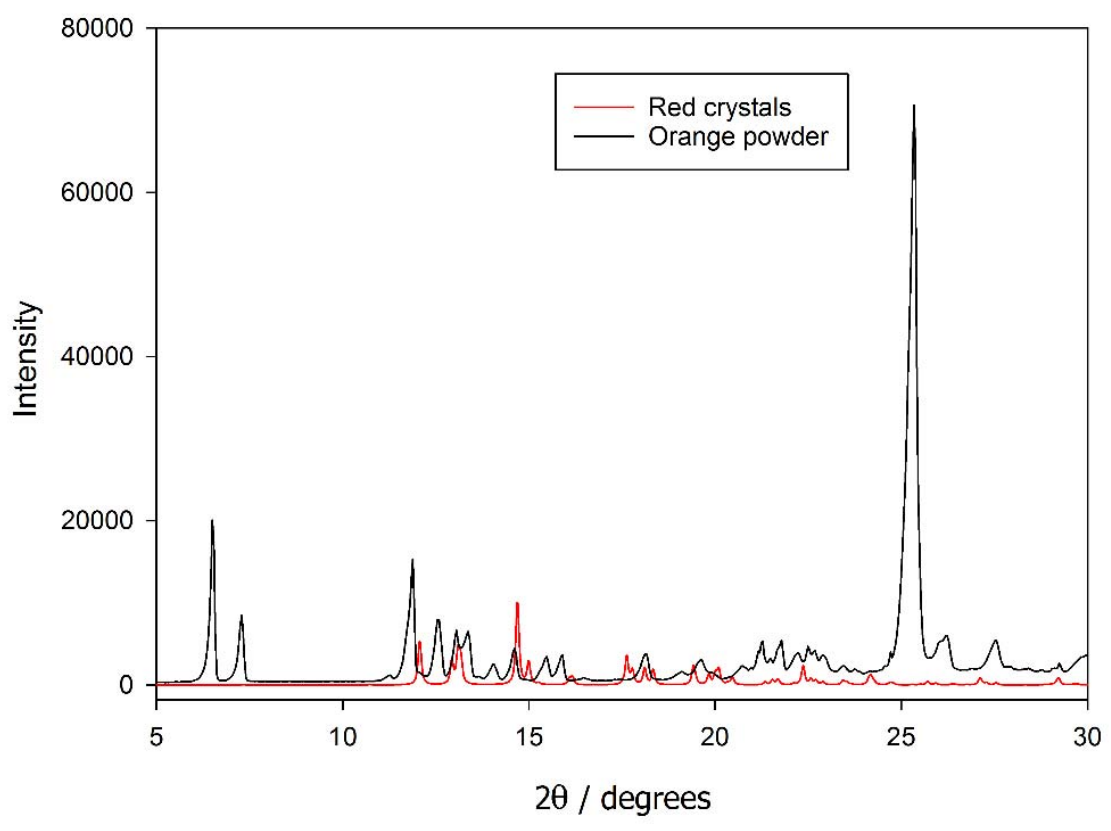

Figure S1: Powder X-ray diffraction pattern of the orange powder of 2e, and calculated pattern of the red crystals of $\mathbf{2 e}$. 


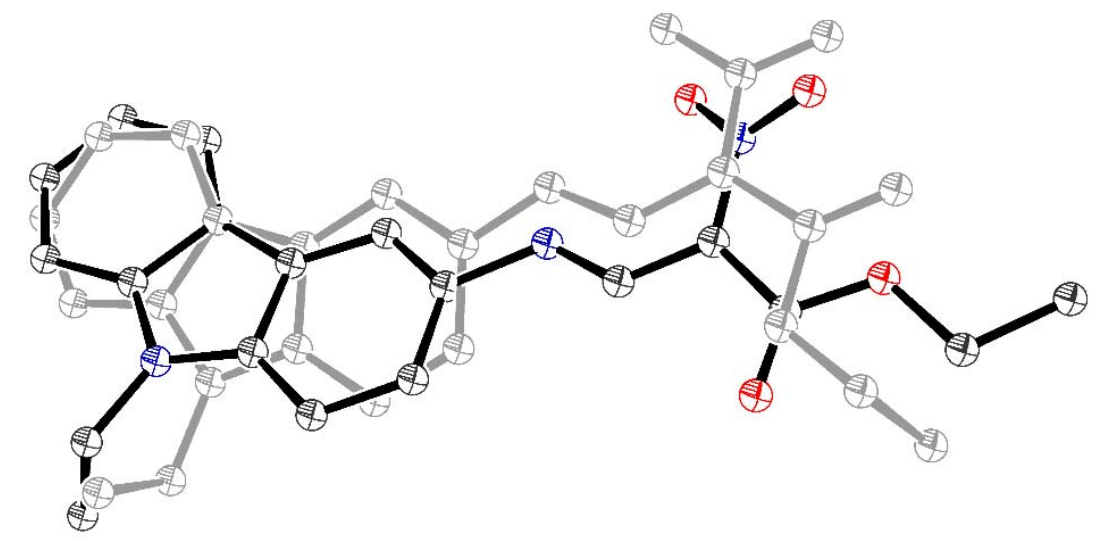

Figure S2: Overlay of the structures of the red and orange crystalline forms of 2e.

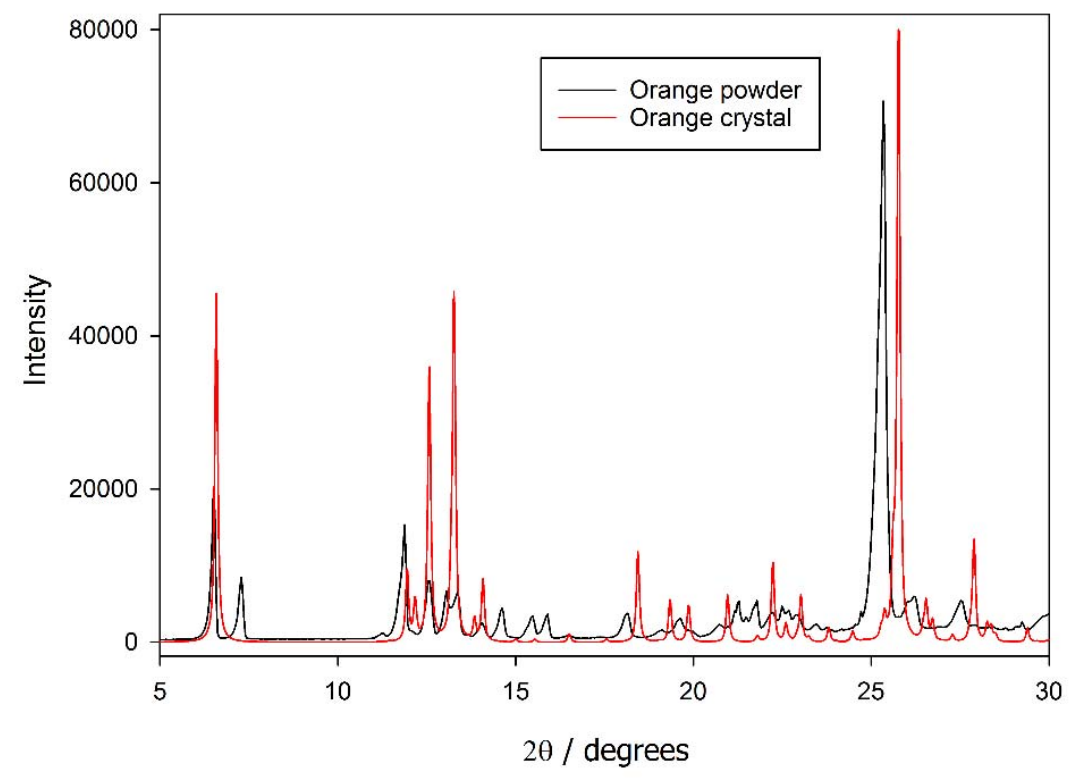

Figure S3: Powder X-ray diffraction pattern of the orange powder of 2e, and calculated pattern of the orange crystals of $2 \mathbf{e}$. 